\title{
41. GEOLOGIC EVOLUTION OF THE SOUTHEAST PACIFIC BASIN
}

\author{
Campbell Craddock, University of Wisconsin, Madison, Wisconsin \\ and \\ Charles D. Hollister, Woods Hole Oceanographic Institution, Woods Hole, Massachusetts
}

\begin{abstract}
During DSDP Leg 35 four holes were drilled in the Southeast Pacific Basin, two located on the Bellingshausen Abyssal Plain (Sites 322,323 ) and two on the upper continental rise of Antarctica (Sites $324,325)$. The objectives of Leg 35 were to determine (1) the age and character of the oceanic basement, (2) the nature of distinctive reflectors in the marine sediments, (3) the sequence and effects of deep and surface paleocirculation patterns, (4) the history of continental glaciation of West Antarctica, (5) the occurrence and distribution of high-latitude fossils, and (6) geochemical gradients in pore waters in the sedimentary sequence. Only limited coring was attempted, and recovery was modest; totals for the four holes are 2211 meters of penetration, 55 cores attempted, 515 meters of core cut, and 193 meters of core recovered. At Site 322 the hole penetrated 514 meters of Quaternary and Neogene detrital sediments and 30 meters into basalt. At Site 323 the hole penetrated 701 meters of QuaternaryNeogene detrital sediments and Paleocene-Cretaceous pelagic sediments and 30 meters into basalt. At Site 324 the hole penetrated 218 meters of Quaternary and Pliocene detrital sediments before failing in caving sand. At Site 325 the hole penetrated 718 meters of Quaternary and Neogene detrital sediments. The ages of the oceanic basement are Paleocene (?) at Site 322, late Cretaceous at 323, Paleocene (?) at 324, and late Oligocene at 325 . The basalts at the two abyssal plain sites are normal oceanic tholeiites except for potash enrichment; the rock at Site 322 is a submarine lava flow with minor alteration, that at 323 comprises one or more sills and shows more alteration and many calcite veins.

The pelagic Maestrichtian-Danian beds at Site 323 are mainly brown claystones with fine-grained volcanic components, and they are enriched in iron, manganese, barium, and other elements; the sediment accumulation rate was about $0.5 \mathrm{~cm} / 1000 \mathrm{yr}$. The Neogene-Quaternary sediments at all sites are clays, silts, and sands brought from Antarctica mainly by turbidity currents but commonly reworked by bottom currents; accumulation rates were generally $2-3$ $\mathrm{cm} / 1000 \mathrm{yr}$ but reached $10-20 \mathrm{~cm} / 1000 \mathrm{yr}$ in the latest Miocene and early Pliocene. Moderately well preserved siliceous microfossils occur in middle Miocene and younger beds, arenaceous foraminifera in lower Miocene beds, and calcareous foraminifera and nannoplankton in the pelagic Maestrichtian-Danian beds. These fossils indicate that the oldest sediments penetrated were lower Pliocene at Site 324, lower Miocene at 322 and 325, and uppermost Cretaceous (Maestrichtian) at 323; probable unconformities occur at the base of the lower Miocene at Sites 322 and 323 . The lower sediments commonly show cementation by calcite and/or silica as a result of the dissolution of microfossil tests; authigenic minerals such as illite/smectite, clinoptilolite, and potash feldspar are also present. Interstitial pore waters show downhole decreases in dissolved magnesium and potassium along with an increase in dissolved calcium. Magnesium is depleted by the formation of montmorillonite, and potassium by the formation of zeolites and feldspar; the increase in calcium results from the alteration of plagioclase and pyroxene in basalt and detrital sediments.

Foraminifera assemblages indicate water depths of 1500-2000 meters during the Danian at Site 323 and of more than 2000 meters during the early Miocene at Sites 322, 323, and 325. The sediments at all four sites accumulated at bathyal to abyssal depths, mainly below the carbonate compensation depth: a downward fluctuation of the carbonate compensation depth during the Danian is recorded in the
\end{abstract}


sediments at Site 323 . Sediment scour during the Oligocene or early Miocene, inferred at Sites 322 and 323, is attributed to the inception of the Antarctic Circumpolar Current. A westward-flowing countercurrent, following the contours along the upper continental rise, seems to have formed during the Miocene. Siliceous fossil abundances suggest that a major cooling of the seas occurred during the middle Miocene and that the polar front reached Site 322 by the late Miocene. Ice-rafted debris is scarce in the sediments at the abyssal plain sites, but common at the upper continental rise sites. The age of the oldest ice-rafted debris is late Miocene at Site 322, probably middle Miocene at 323, early Pliocene (from bottom of deepest core) at 324 , and early Miocene (16-17 m.y. B.P.) at 325.

The area of Leg 35 drilling seems to have been a deep oceanic region since the late Paleozoic or earlier, a part of the vast sea that formerly bordered Gondwanaland, but no oceanic crust older than Cretaceous has been discovered here. The Pacific-Antarctic Ridge existed by Cretaceous time, and its westward propagation helped to fragment Gondwanaland, detaching New Zealand about 81 m.y.B.P. and Australia about 55 m.y. B.P. To the south another spreading axis parallel to the margin of West Antarctica and the Antarctic Peninsula may have formed during the Cretaceous; it seems to have propagated northeastward. The southwestern segment of this system was subducted beneath West Antarctica during the Eocene, but the segment to the northeast was activated during the Eocene and subducted beneath the Antarctic Peninsula in the early Miocene. The southern Chile Ridge may also have formed in the Eocene or Oligocene and have been subducted beneath southern South America in the early Miocene. Thus in late Paleogene time a triple junction may have formed west of the South America-Antarctic Peninsula land connection, creating the Scotia Sea by north-south spreading on the east limb and opening a passage which allowed formation of the Antarctic Circumpolar Current. This newly formed Scotia plate, caught between the South American plate and the Antarctic plate, may then have been displaced westward and overridden the triple junction.

The glaciation of West Antarctica may have begun in the Eocene, but it was certainly underway by the Miocene. Interpretation of the sediments cored suggests that Antarctic glaciation was weak in the early Miocene, moderate by middle Miocene, extensive by late middle Miocene, and fully developed by sometime in the late Miocene. The intensity of glaciation subsequently declined, with several fluctuations, during the Pliocene and the Quaternary to its present moderate to extensive state.

\section{INTRODUCTION}

The Southeast Pacific Basin is a poorly known region of great importance to the solution of several major problems. The objectives of Leg 35 were to determine (1) the age and nature of the oceanic basement to achieve better understanding of the configuration and fragmentation of Gondwanaland, (2) the nature of distinctive reflecting horizons in the marine sediments which may record major geologic and oceanographic events such as the development of the Antarctic Circumpolar Current, (3) the sequence and effects of deep and surface paleocirculation patterns as reflected in biological productivity and sedimentation events, (4) the history of continental glaciation of West Antarctica, (5) geochemical gradients in pore waters in the sedimentary sequence and their relation to solid phases of the sediment and to submarine alteration of basement rock, and (6) the occurrence and distribution of high-latitude fossils to help establish an Antarctic biostratigraphic and paleogeographic framework.

Although more than a dozen sites were originally planned, we were only able to attempt four holes (Figure
1) in the limited time available. The ship was delayed 10 days for repairs at the start of Leg 35, and the long transit from Callao, Peru, to our drilling area was interrupted by a stop in Valparaiso, Chile, for supplies and personnel. After leaving the Chilean coast, the ship faced adverse sea and weather conditions during most of the remaining days of the cruise. A number of mechanical failures plagued cruising and drilling operations at sea, and in addition, it was necessary to invest some time in sea testing of a new heave compensator during drilling. The time devoted to actual drilling and coring totaled a little less than 8 days.

In this synthesis chapter we outline the principal scientific results of this drilling expedition and try to integrate other existing data pertinent to our objectives. The first sections treat the individual topics of investigation, and the final parts present a brief resume of the inferable geologic history of the region. In a strict sense our results apply directly to the area of Leg 35 drilling, the Bellingshausen Sea region, including the Bellingshausen Abyssal Plain and the continental rise off West Antarctica. However, in a broader way this new information concerns the entire Southeast Pacific Basin 


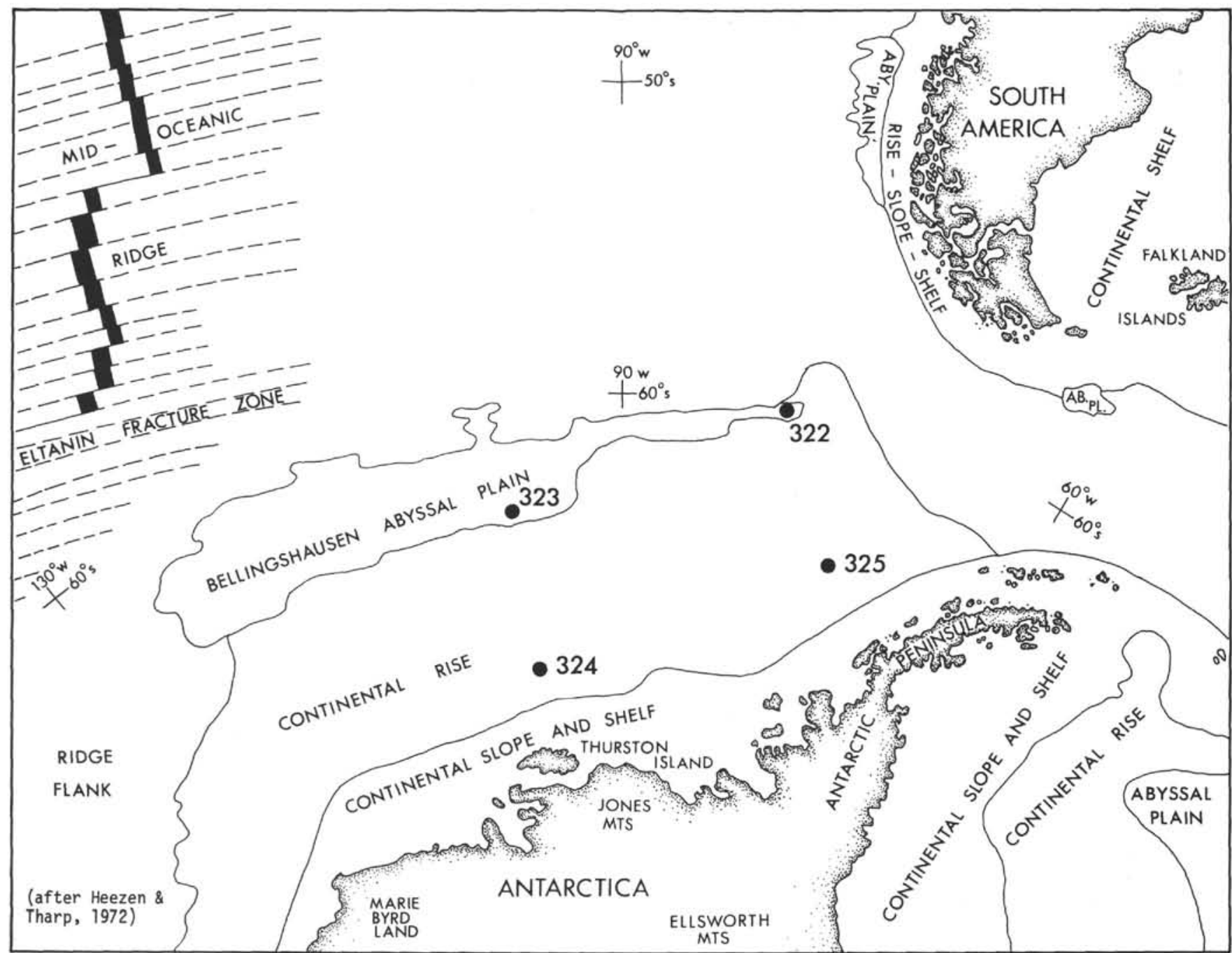

Figure 1. Generalized bathymetric provinces of the Southeast Pacific Basin and location of Leg 35 sites (after Heezen and Tharp, 1972).

northward to the Pacific-Antarctic Ridge and the Chile Ridge because the Bellingshausen Sea region is thought to contain the oldest crust and the most extensive sediment cover. Moreover, this is an appropriate time to attempt a synthesis since it is unlikely that additional drilling will be undertaken in this area soon.

The sediment maps of Lisitzin (1973) illustrate well the sparsity of information about the pre-Quaternary history of the Bellingshausen Sea region. Saito et al. (1974) report on piston cores and dredgings which contain Pliocene or older fossils. The southern Southeast Pacific Basin has yielded many sites with Pliocene sediments, one with Oligocene, and one with Eocene sediments. The bathymetric and tectonic provinces near Antarctica are discussed and illustrated by Heezen and Tharp (1972), and Goodell (1973) reviewed knowledge of the recent marine sediments, including the results of many Eltanin cruises. A summary of the sea-floor microphysiography and sedimentary features related to present-day bottom circulation is given by Hollister and Heezen (1967) and Heezen and Hollister (1971). Heirtzler (1971) offers a model for the evolution of the southern oceans. Bushnell and Craddock (1970) and
Craddock (1972b) portray the geology of Antarctica in a series of maps.

\section{MORPHOLOGY OF THE SEA FLOOR}

The submarine morphologic provinces of the Bellingshausen Sea region include the Antarctic continental shelf, slope, and rise, the Bellingshausen Abyssal Plain, and the abyssal hills-arranged in northward sequence (Figures 1, 2, and 3). The shelf is narrow off the northern Antarctic Peninsula but widens to the southwest, and reaches about 200 miles $(320 \mathrm{~km})$ in width in the Bellingshausen Sea; the width within the varying segments is probably related to the time interval since the termination of subduction. In places the shelf is cut by transverse or longitudinal channels, and there is commonly a lip at the outer edge. The break to the continental slope is distinct; it occurs at 230 fathoms (420 $\mathrm{m})$ in the northeast, but it approaches a depth of 300 fathoms $(550 \mathrm{~m})$ to the southwest. The continental slope is narrow and steep (as much as $11^{\circ}$ ) off the northern Antarctic Peninsula, but it becomes wider and gentler southwestward. 
న్

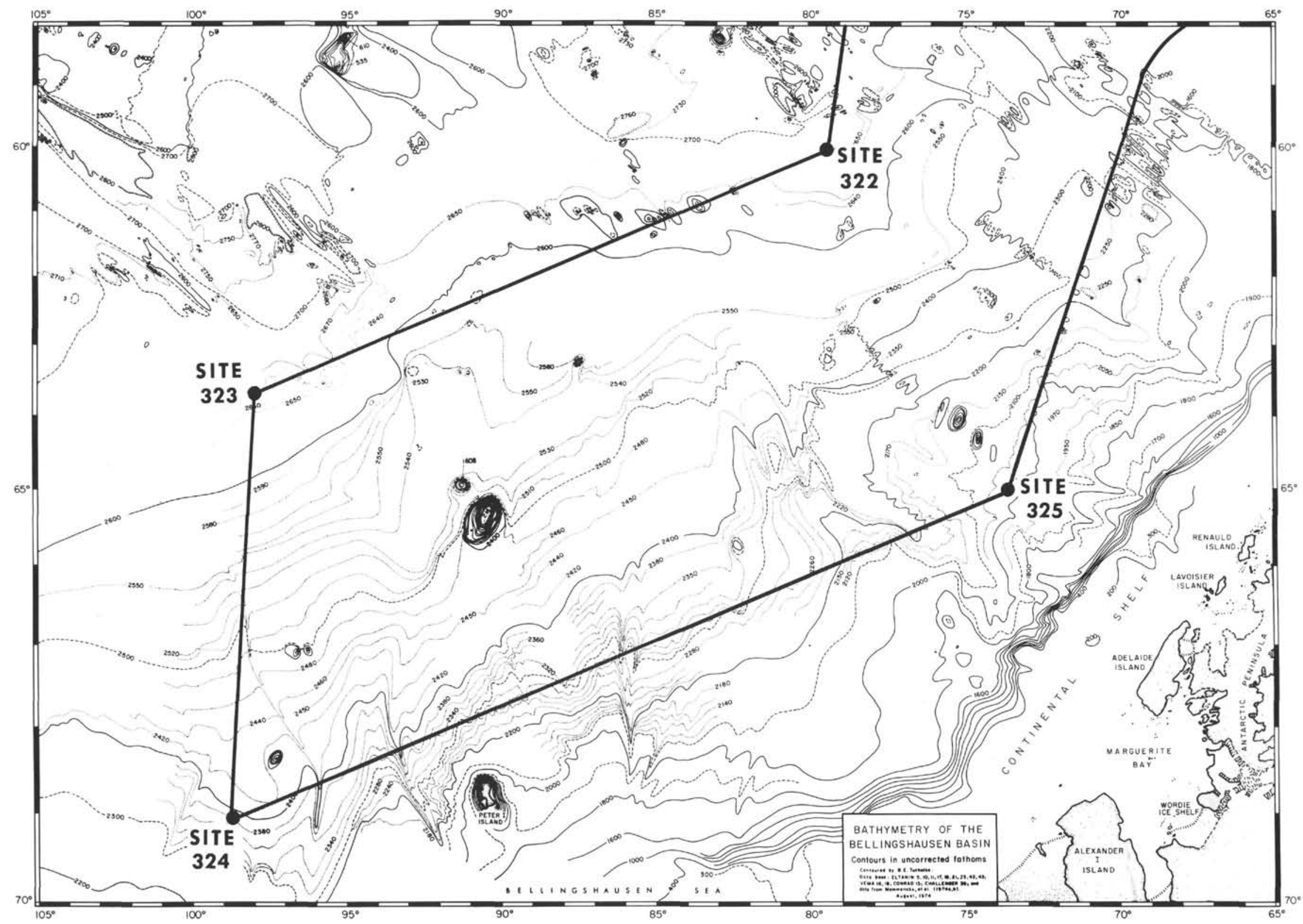

Figure 2. Bathymetric map of the southern Southeast Pacific Basin (after Tucholke, foldout, this volume). 


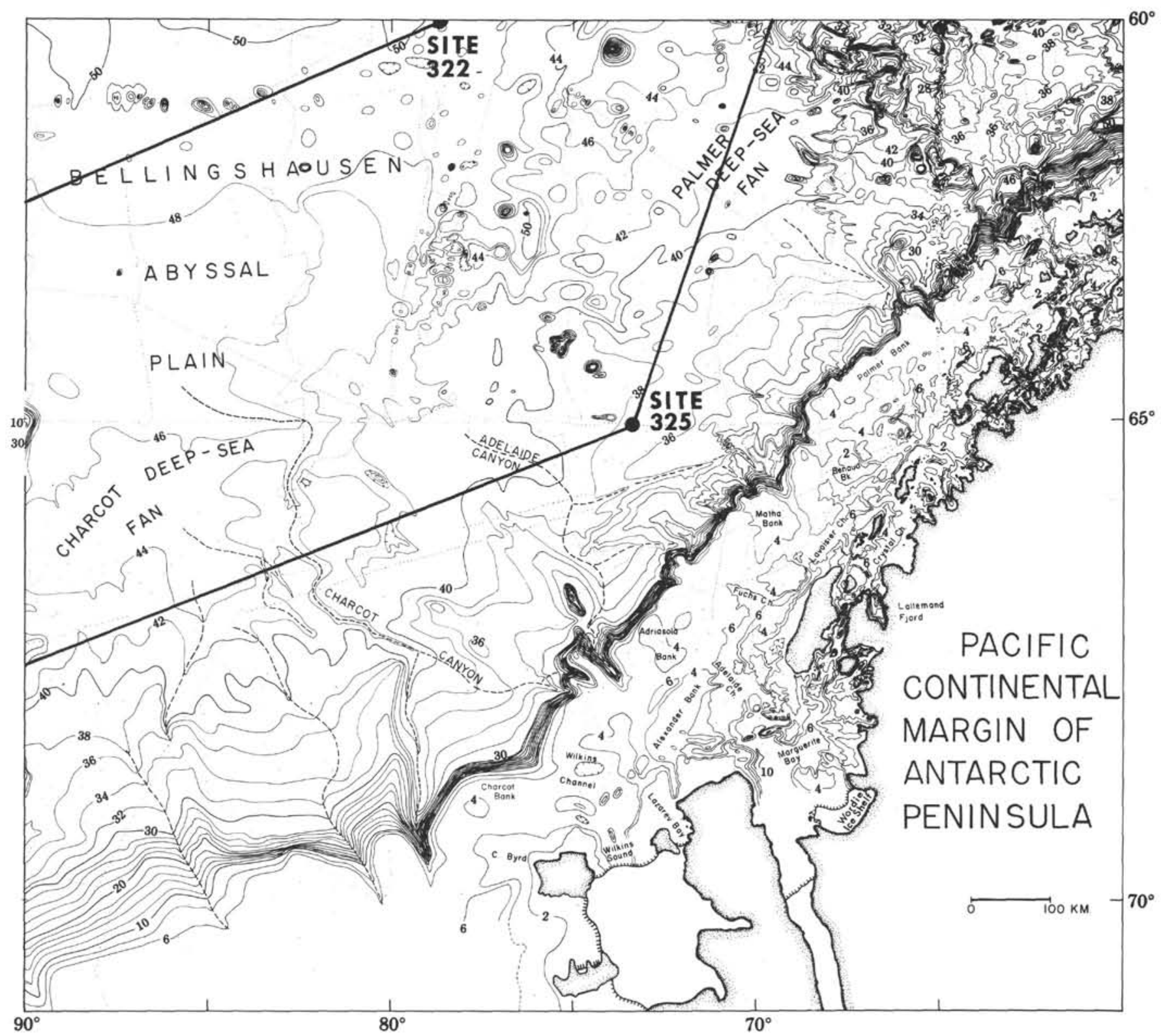

Figure 3. Bathymetric map of the Pacific continental margin of the Antarctic Peninsula (after Vanney and Johnson, this volume). Contours are in hundreds of meters.

The continental rise is marked by distinct channels and associated sediment waves and dunes, and deep-sea fans occur at the foot of some channels. Several fracture zones cut the rise and affect the sediment thickness patterns; the rise is well developed except northeastward from the Hero Fracture Zone (Figure 4). Between the Hero and Tula Fracture zones the lower rise is interrupted by the Palmer Ridge, a northeast-trending belt of rough basement. In the southern Southeast Pacific Basin several seamounts and one volcanic island occur on the continental rise (Figure 2).

The abyssal plain lies below about 2500 or more fathoms $(4560 \mathrm{~m})$, and normally a few hundred meters of sediment overlies the deepest observed reflector. Seismic basement is generally smooth, but a few rocky peaks stand above the plain. In contrast, the abyssal hills are a rugged and complex province, cut by fracture zones and typical of ridge-flank topography. Most of these hills are swept by the Antarctic Circumpolar Current, and sediment ponds occur at different levels. Some hills appear to be barren of any sediment, and there are some sediment-free deeps as well.

\section{AGE OF THE OCEANIC BASEMENT}

Information about the age of the oceanic basement at a particular site can be obtained from (1) regional magnetic anomaly patterns, (2) depth of the basement below sea level, (3) ages of fossils in the overlying sediments, (4) radiometric ages on igneous rocks from inferred basement, and (5) measurements of density and velocity on basaltic rocks from inferred basement. It is possible that none of the four Leg 35 holes reached true 


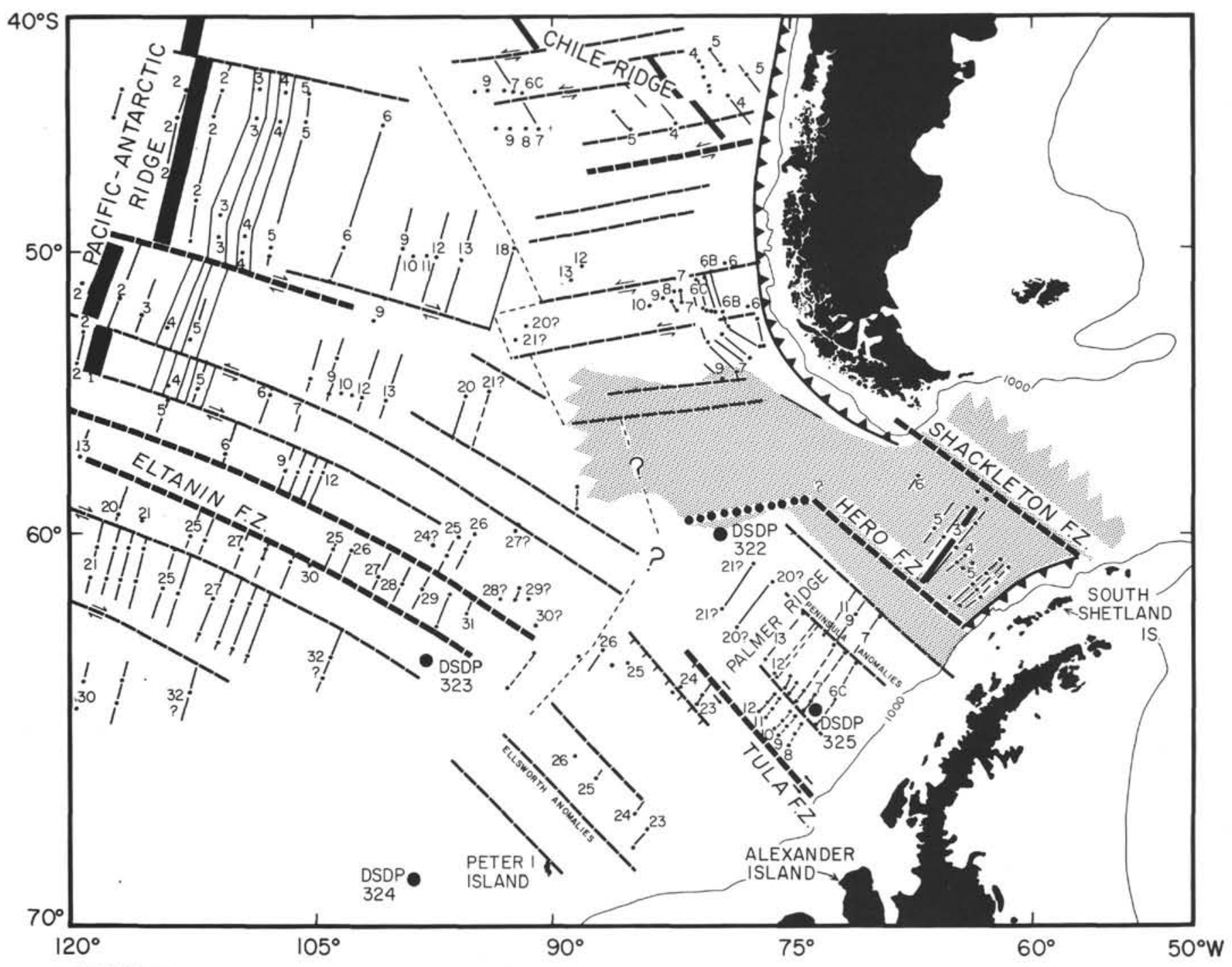

ANOMALY NO.

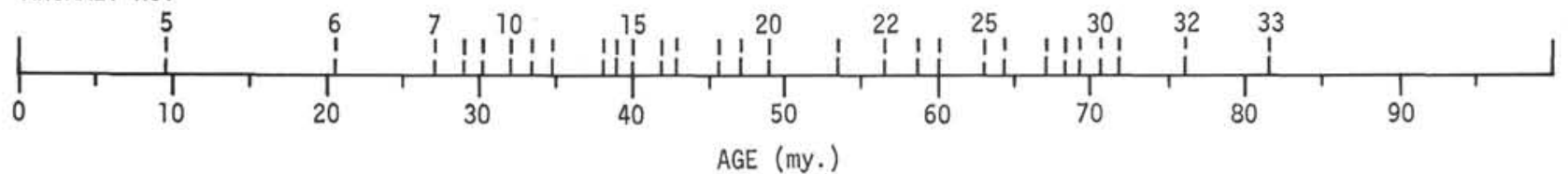

Figure 4. Magnetic anomalies and principal structural features in the Southeast Pacific Basin (after Herron and Tucholke, this volume).

oceanic basement. However, both abyssal plain holes, Sites 322 and 323 , bottomed in basaltic rocks which are probably within or very close to true basement.

Five sets of magnetic anomalies have been identified in the Southeast Pacific Basin (fig. 4, from Herron and Tucholke, this volume). One set near the PacificAntarctic Ridge trends north-northeast, one set near the Chile Ridge trends north-northwest, and three sets off the Antarctic Peninsula trend northeast; in sequence toward the southwest these latter sets are the Drake Passage, Peninsula, and Ellsworth anomalies. Although Katz (1972) suggested that oceanic crust as old as Jurassic might exist in the Bellingshausen Sea region, the Late Cretaceous anomalies southeast of the PacificAntarctic Ridge appear to be the oldest in the region.
The history of the Chile Ridge south of $46^{\circ}$, where it intersects South America, is poorly known; it appears to have become active during the Eocene or Oligocene and to have been overridden by South America during the Miocene. The Drake Passage anomalies are interpreted as having formed during the interval from about 20 to 45 m.y.B.P. The Peninsula anomalies were probably forming by earliest Eocene and continued until the Miocene when the spreading axis (Aluk Ridge) was overridden by the Antarctic Peninsula. The Ellsworth anomalies are poorly documented, but they suggest rapid spreading during latest Cretaceous and Paleocene time.

Although but sketchily known in much of the area, these magnetic anomaly patterns allow a rough base- 
ment age prediction at each site. Unfortunately Site 322 lies in an area of poorly defined magnetic anomalies, and determination of its basement age is speculative. If from the Pacific-Antarctic Ridge, it should be Cretaceous; if from the former ridge to the southeast, Paleocene or latest Cretaceous; if from the Chile Ridge, possibly younger but probably still early Tertiary. Site 323 should be late Cretaceous, whether from the PacificAntarctic Ridge or from the former ridge to the southeast. Site 324 has very poorly controlled magnetic anomalies, but the crust may be Paleocene on the basis of the closest identified anomaly set northeast of Peter I Island. The well-defined anomaly set near Site 325 indicates a basement age of late Oligocene.

The depth of ridge-generated basement below sea level, corrected for sediment cover, is related to its age (Figure 5, after Herron and Tucholke, this volume). Basement depths suggest ages of Paleocene at Site 322, late Cretaceous (Maestrichtian) at Site 323, and late Oligocene at Site 325; basement depth is unknown at Site 324. Fossils indicate minimum basement ages of early Miocene (possibly late Oligocene) at Sites 322 and 325, Late Cretaceous (Maestrichtian) at Site 323, and early Pliocene at Site 324 (a shallow hole that failed at $218 \mathrm{~m}$ ). Radiometric ages (K-Ar) of about 11 m.y. (middle Miocene) on a probable flow in the bottom of 322 and about 47 m.y. (middle Eocene) on a probable sill in the bottom of Site 323 are considered too young, as is discussed below. Christensen and Salisbury (1972) and Salisbury and Christensen (1973) have shown that the density and velocity of submarine basalts both decrease with increasing age because of alteration; the physical properties of the basalts from Sites 322 and 323 suggest that both these rocks have been in contact with seawater for more than 40 m.y.

In summary, the evidence indicates that the Site 322 basement must be at least about 20 m.y. old, but could well be as old as late Cretaceous. At Site 323 the base-

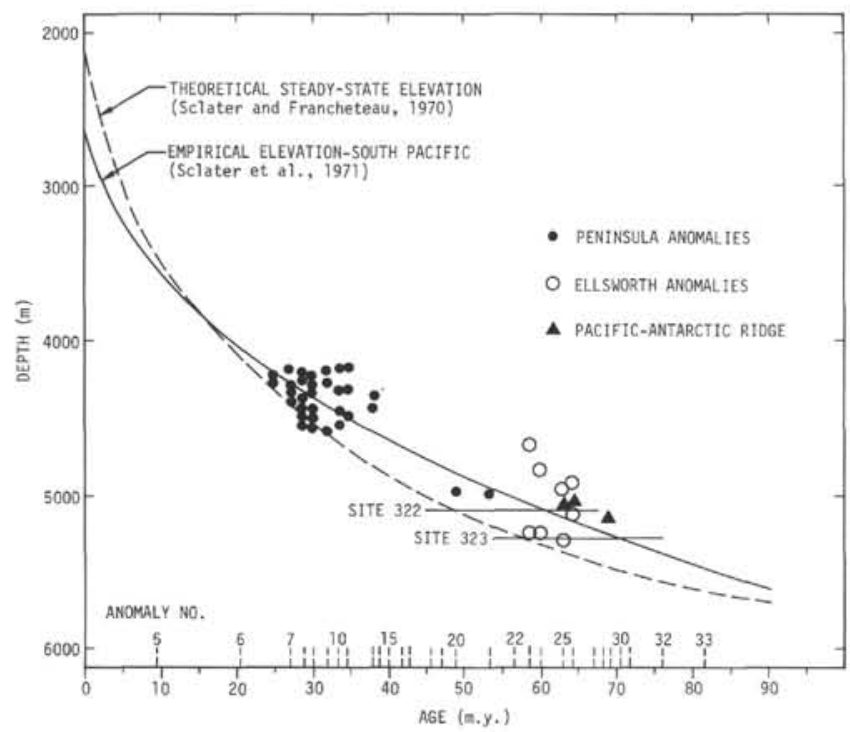

Figure 5. Plot of average depth versus age of basement in the Bellingshausen Basin, corrected for sediment overburden (after Herron and Tucholke, this volume). ment is late Cretaceous, probably Maestrichtian and about 70 m.y. old. The evidence at Site 324 is inconclusive, but the basement is certainly pre-Pliocene and may be Paleocene in age. At Site 325 the magnetic anomalies, basement depth, and fossils all suggest a late Oligocene basement age.

\section{IGNEOUS ROCKS}

Many DSDP holes have penetrated igneous rocks, and Christensen et al. (1973) provide a good review of their distribution and characteristics through Leg 31 . Bonatti (1967) found two eruptive mechanisms in the deep eastern Pacific Ocean: quiet eruptions which yield pillow lavas, and hyaloclastic eruptions which yield fragmental palagonite. On Leg 35 both Sites 322 and 323 were drilled into basaltic rocks which are normal oceanic tholeiites except for their enrichment in potash to $0.81 \%$ and $0.53 \%$, respectively. Engel et al. (1965) give the composition of the average oceanic tholeiite as $49.94 \%$ silica, $2.76 \%$ soda, and $0.16 \%$ potash. On Leg 28 three basalts penetrated in a traverse down the south flank of the Southeast Indian Ridge between Australia and Antarctica were also tholeiites with potash values of $0.76 \%, 0.58 \%$, and $0.43 \%$ (Ford, 1975 ); it is interesting that these potash abundances diminish away from the active ridge crest.

The basalt at Site 322 ranges from glass to holocrystalline basalt, and it is interpreted as a submarine lava flow. Chemically it is a tholeiite, but it is close to the alkali basalt field. It is not clear whether this flow represents true basement. Several seamounts exist in the area, and this rock may be a random intraplate flow. High penetration rates during drilling suggest that true basement may not have been reached, or at least that interbedded sediments were present. On the other hand, the interpretation that basement was reached is favored by (1) the similarity to other DSDP basalts considered to be basement, (2) the absence of any observed deeper reflectors, and (3) the lateral continuity of acoustical basement beneath most of the abyssal plain. Thus, this rock can be interpreted as (1) a random middle Tertiary sea-floor lava flow, (2) middle Tertiary basement from an unknown source, or (3) an older basement swept clean by middle Tertiary bottom currents. A late Cretaceous or early Tertiary basement could have formed at one of three possible source ridges, but there is no presently known source for a middle Tertiary basement. The occurrence of fresh glass may favor a Tertiary age, but Bonatti (1965) found that palagonite devitrifies much faster than unhydrated glass.

The basalt at Site 323 shows a range of textures, and it is interpreted as comprising one or two sills. Thus, this rock is probably not true basement, but McBirney (1971) suggests that sills rarely if ever form very far above the base of the sediment blanket. The rock has the mineralogy and chemistry of an ocean-ridge tholeiitic basalt, but the potash is high and the composition close to that of alkali basalt. Calcite veins are common, and smectite occurs on some fracture surfaces and in some amygdules. High iron and titanium and low magnesium contents suggest considerable fractionation. Normative calculations place the rock in the oversaturated tholeite field. 
The basalts at both sites have undergone considerable, though somewhat different, submarine alteration; its effect in reducing density and velocity has already been discussed. Site 322 shows less alteration in the form of poorly recrystallized smectite, phillipsite, and minor calcite. At Site 323 low-temperature hydrothermal alteration under a thin sedimentary blanket has produced well-recrystallized smectite, celadonite, goethite, and abundant calcite, the last formed through decomposition of organic matter in the overlying sediments. The alteration of these rocks, like other DSDP basalts, complicates the problem of rock classification (Bence et al., 1973).

The $\mathrm{K}-\mathrm{Ar}$ apparent ages on the basalts at both sites are probably younger than the true ages, most likely because of the addition of potassium to the rock during alteration. Hart (1970) has shown that basalts react with seawater to become more alkaline, acting as sinks for potassium and sodium. As discussed above, the calculated age of 11 m.y. at Site 322 conflicts with the early Miocene fossils in the sediments which overlie this flow. At Site 323 the age of $47 \mathrm{~m} . \mathrm{y}$. is more than $20 \mathrm{~m} . \mathrm{y}$. younger than the inferred basement age; this calculated age may be an incorrect age, or it may indicate a later sill. Ozima et al. (1973) also found K-Ar ages less than the overlying sediments for basalts from Legs 7 and 17 . In summary, it is possible that true oceanic basement was not reached at either site; thin sedimentary deposits may be present at greater depth, particularly at Site 323 .

\section{SEDIMENTARY DEPOSITS}

Almost all the sediments penetrated at the four Leg 35 sites consist of detritus derived from Antarctica (Figure 6 ). However, thin pelagic deposits occur just above the basalt in the two abyssal plain sites $(322,323)$. Seismic profiler and echo sounding data show that the sedimentary blanket thins seaward from Antarctica, and there is no bathymetric conduit for the transport of material from South America, suggesting that there is no sediment contribution from that continent. Sediment accumulations beneath the continental rise increase in a southwestward direction, and thicknesses greater than 2500 meters occur southwest of the Tula Fracture Zone. Data on the shelf are limited, but Ashcroft (1972) discovered as much as $6 \mathrm{~km}$ of sediments just northwest of the South Shetland Islands by seismic refraction studies. Although a trench exists near the South Shetland Islands, no evidence for a trench has been found to the southwest of the Hero Fracture Zone.

The main factors which have affected the composition of the sediments in the Bellingshausen Sea region are (1) tectonic evolution of Antarctica and the adjacent sea floor, (2) patterns of current flow, (3) Antarctic glaciation, (4) biological productivity, and (5) diagenesis. In the three deep holes the sediments become consolidated below a depth of about 300 meters, and physical properties show a good correlation with seismic profile units. Sonic velocity increases downward, and below about 200 meters there is a small but distinct velocity anisotropy.

The provenance of all the detritus recovered appears to be from outcrops in West Antarctica and the Antarctic Peninsula. The heavy minerals are mainly pyroxene and amphibole. Those at Sites 322 and 325 resemble the Andean instrusive suite of the Antarctic Peninsula and those at Sites 323 and 324 probably came from the Eights Coast and possibly the Jones Mountains. The clay minerals are mainly chlorite, illite, smectite, and mixed-layer varieties probably derived from the mechanical weathering of Antarctic rocks and from postdepositional alteration of sediments; montmorillonite is important in the older pelagic sediments. The distribution of clay minerals in the oceans shows marked latitudinal variation (Biscaye, 1965; Turekian, 1965; Griffin et al; 1968, Rateev et al., 1969); the kaolinite/chlorite ratio diminishes sharply from the equator toward the high latitudes. Thus the clay mineral suite in the detrital sediments is normal for high-latitude deposits. Biogenic silica and authigenic minerals also comprise significant components of these mainly detrital sediments.

The basal pelagic beds at Sites 322 and 323 are brown claystones, with an important volcanic component, which are enriched in iron, manganese, barium, and other elements. They apparently accumulated in a tranquil, oxidizing environment. Enrichment is more pronounced in the pelagic unit at Site 323, and detrital materials are present in the basal beds at Site 322 . Metalliferous enrichment of sediments along the crest of the East Pacific Rise, in a zone of high heat flow and volcanic exhalations, has been described by Böstrom and Peterson $(1966,1969)$ and by Böstrom et al. (1969), and this process probably caused the enrichment of our pelagic beds, at least at Site 323. Elderfield (1972) reports addition of manganese to seawater by fumarolic activity prior to the 1969 eruption of Deception Island in the South Shetland Islands.

Frakes and Kemp (1972) offer a sea-floor spreading model which predicts that a thin basal "ridge-facies" layer should occur just above basement on the flanks of the ridge. Cronan et al. (1972) found such enriched beds in the basal unit at Sites 159 and 162 in the eastern equatorial Pacific, and Davies and Supko (1973) summarize the occurrence of iron-rich basal sediments at 19 DSDP sites. The basal unit at Site 323 seems very similar to these occurrences and probably formed in a shallower ridge-crest environment. If the basalt at Site 322 has an unconformity at its upper surface, the overlying slightly enriched sediments there are probably of a different origin.

Three kinds of currents have played important roles in the transport and deposition of the detrital sediments above these basal units. Turbidity currents probably have been the principal means by which continental debris reached the deep sea although contour-following bottom currents have commonly reworked the sediment before final deposition. Ewing et al. (1969) noted that sediment cores from near Antarctica are unusual in seeming to lack turbidites in the upper 20 meters. This may be at least partially a result of the vigorous Antarctic Circumpolar Current which has existed in this region since early Miocene times and which has probably strongly affected the bottom sediments, even on the abyssal plain (Hollister and Heezen, 1967). During the same interval a westward-flowing contour current seems to have influenced deposition on the continental rise to 


\begin{tabular}{|c|c|c|c|}
\hline \multicolumn{2}{|c|}{ BELLINGSHAUSEN ABYSSAL PLAIN } & \multicolumn{2}{c|}{ ANTARCTIC CONTINENTAL RI SE } \\
\hline SITE 322 & SITE 323 & SITE 324 & SITE 325 \\
\hline $60^{\circ} 01.4^{\prime}$ 'S, $79^{\circ} 25.5^{\prime} \mathrm{W}$ & $\begin{array}{l}63^{\circ} 40.8^{\prime} \mathrm{S}, 97^{\circ} 59.7^{\prime} \mathrm{W} \\
\text { WATER DEPTH } 5026(\mathrm{~m})\end{array}$ & $\begin{array}{l}69^{\circ} 03.2^{\prime} \mathrm{S}, 98^{\circ} 47.2^{\prime} \mathrm{W} \\
\text { WATER DEPTH } 4449 \text { (m) }\end{array}$ & $\begin{array}{l}65^{\circ} 02.8^{\prime} \mathrm{S} 73^{\circ} 40.4^{\prime} \mathrm{W} \\
\text { WATER DEPTH } 3745 \text { (m) }\end{array}$
\end{tabular}

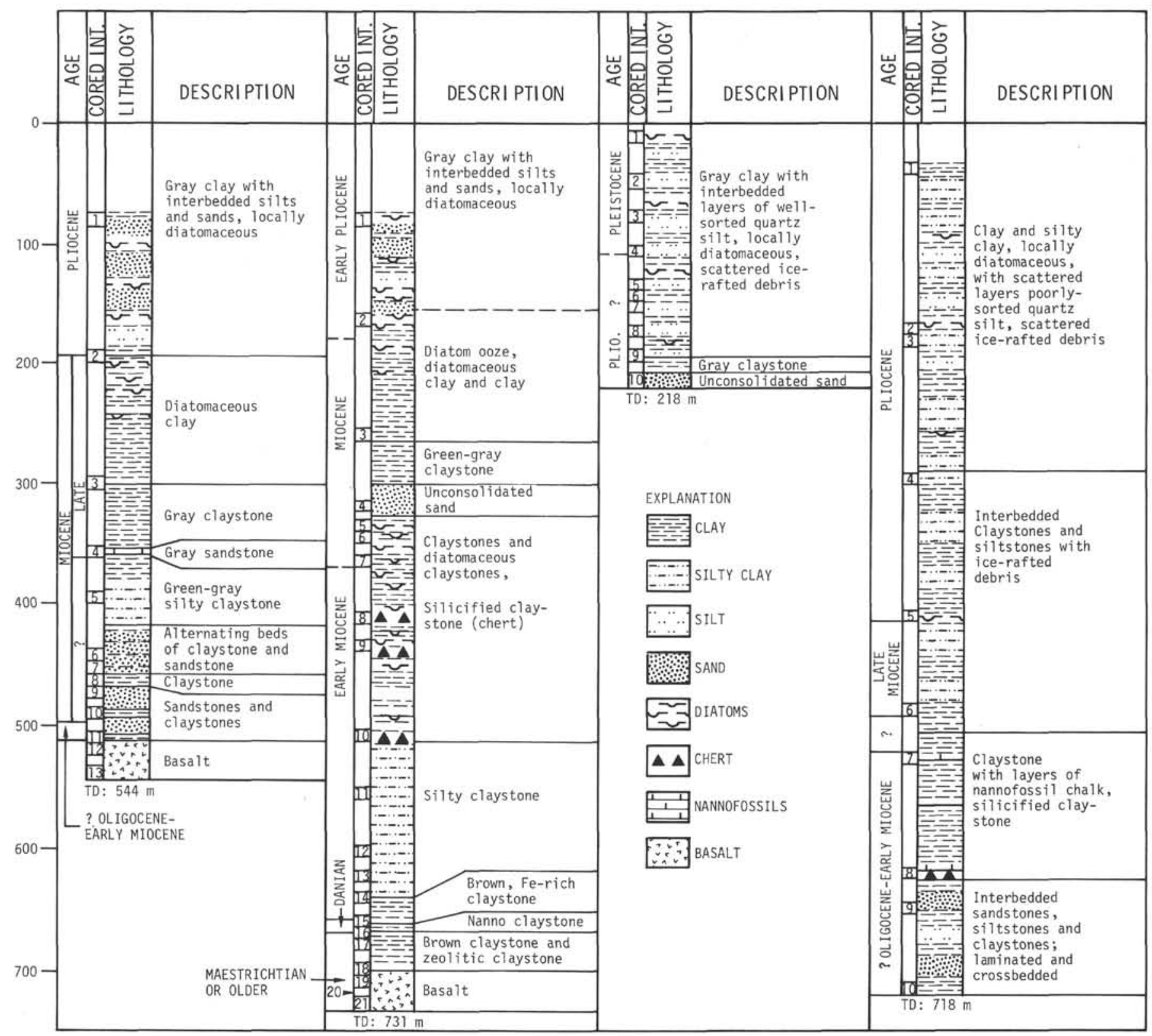

Figure 6. Stratigraphic columns of the four holes drilled during DSDP Leg 35.

the south, forming sediment waves and dunes near the channels (Figure 7). Kolpack (1967) reports a strong modern bottom current in the northern Drake Passage, but a weaker current and poor sediment sorting to the south.

Each site reveals certain distinctive and important sedimentary features. At Site 322 the basal 4.3 meters of claystone with detrital components is overlain by more than 500 meters of detrital sandstone and claystone which consists mainly of turbidites that have been reworked and sorted by abyssal bottom currents. The abundance of siliceous microfossils in the upper part of the sequence suggests that the Antarctic Polar Front reached this site during the late Miocene. At Site 323 the Maestrichtian and Danian pelagic beds seem to be separated by an unconformity from the overlying Miocene and younger detrital sequence which is composed principally of turbidites with some evidence of sorting by bottom currents. Little ice-rafted debris was found in the sediments at either of these abyssal plain sites.

Sites 324 and 325 were drilled on the upper continental rise off West Antarctica. At Site 324 (bottom in lower Pliocene) the predominant clays contain interbeds of 


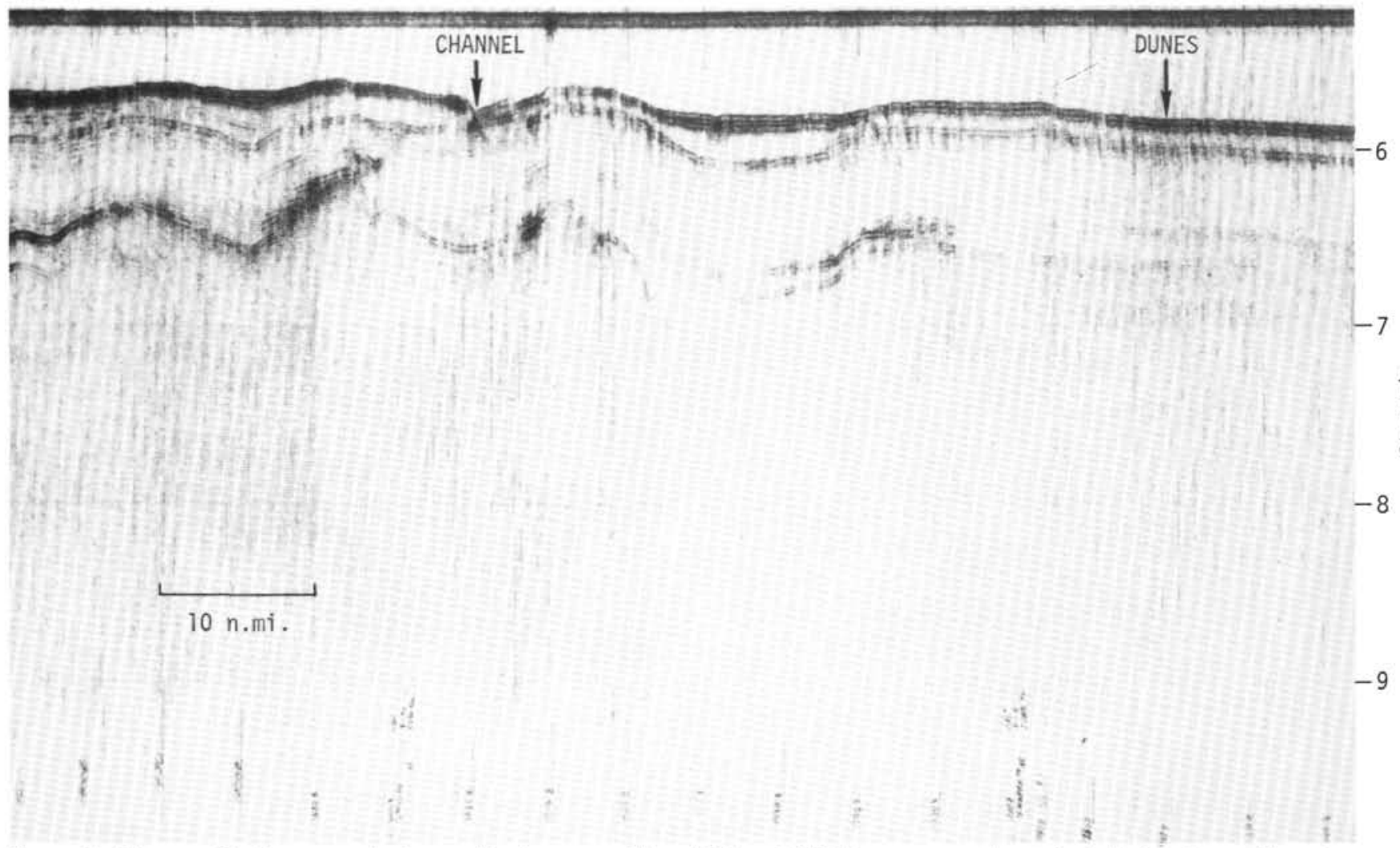

Figure 7. Glomar Challenger seismic profile between Sites 324 and 325 (upper continental rise) showing sediment waves, dunes and channel. (Profile between $68^{\circ} 02^{\prime} \mathrm{S}, 91^{\circ} 47^{\prime} \mathrm{W}$ and $67^{\circ} 40^{\prime} \mathrm{S}$ and $89^{\circ} 40^{\prime} \mathrm{W}$ in water depths of between 4160 and 4360 meters.)

well-sorted silt which we interpret as deposited from contour currents which have entrained fine sediment from turbidity currents moving down the numerous and well-developed channels. Silt layers decrease upward in the sequence, along with an upward increase in icerafted debris and diatoms. The minor amount of volcanic glass may have come from the Jones Mountains to the south. At Site 325 the detrital sequence contains many turbidites, some contourites, and much icerafted debris; some of the sediments display contorted beds and minor faults. The lower 90 meters of coarse clastic sediments may represent influx to the northwestern slope of the former marginal trench.

A sedimentary model is proposed (Tucholke et al., this volume) which describes four stages in the glaciation of Antarctica and the effect of each stage on sedimentation patterns on the upper continental rise and on the abyssal plain (Figure 8). With weak continental glaciation there is strong diatom production above the upper rise; turbidites and ice-rafted debris are minor, and contourites are rare. With moderate glaciation the polar front shifts northward, and there is more ice-rafted debris on the upper rise; more turbidites are formed, but contourites remain scarce. With extensive glaciation floating ice shelves are formed, and because melting on the bottom surface results in deposition of debris well shoreward of the ice shelf margin (assuming that the shelf ice is not dry-based), little ice-rafted debris reaches the deep sea; turbidites are numerous and contourites are mainly clay deposited from a nepheloid layer flowing with the Circumpolar Counter Current. Full glacia- tion brings grounded ice on much of the shelf, and abundant ice-rafted debris reaching far to the north. The ice scours valleys and truncates older beds on the shelf. Turbidites are abundant, and the numerous contourites consist of well-sorted silt pirated from the turbidity currents. It is evident that no simple and direct relationship exists between the intensity of Antarctic glaciation and the individual textural and compositional sedimentary parameters such as abundance of ice-rafted debris; this also has been emphasized by Keany et al. (1974) and Watkins et al. (1974).

Sediment accumulation rates for the older pelagic sediments at Sites 322 and 323 are poorly known but are probably less than $0.5 \mathrm{~cm} / 1000 \mathrm{yr}$. At all sites Neogene detrital sediment accumulation was mainly in the range of $2-3 \mathrm{~cm} / 1000 \mathrm{yr}$ except during the latest Miocene and early Pliocene when rates reached $10-20 \mathrm{~cm} / 1000 \mathrm{yr}$; the high rates are probably related to intensive Antarctic glaciation. In comparison, Goodell (1969) reported Quaternary sedimentation rates of more than $2 \mathrm{~cm} / 1000$ $\mathrm{yr}$ on the upper continental rise, but less than 0.2 $\mathrm{cm} / 1000 \mathrm{yr}$ to the north under the Antarctic Circumpolar Current. Payne et al. (1972) found a Quaternary sedimentation rate of $5 \mathrm{~cm} / 1000 \mathrm{yr}$ on the Wilkes Abyssal Plain where the sediments are mainly turbidites.

\section{PALEONTOLOGY}

Moderately well preserved siliceous microfossils (diatoms, radiolarians, and silicoflagellates) were recovered at all four sites in beds as old as middle Miocene, but in the deeper sediments these fossils have 
NORTH
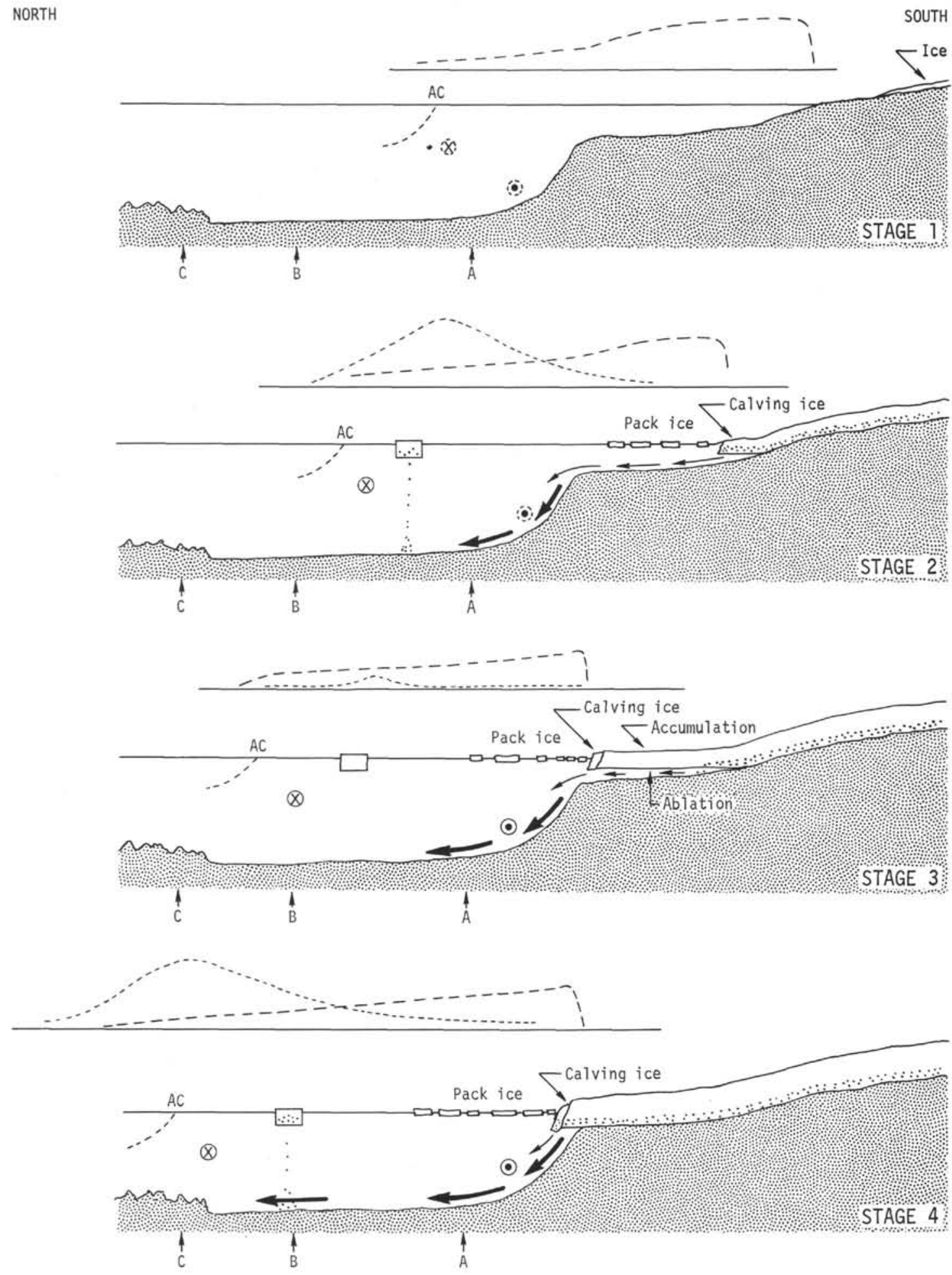

CURRENTS

$\otimes$ Antarctic Circumpolar

- Countercurrent

i: Weakest

Ostrongest
$A C$ - Antarctic Convergence (Polar Front Zone)

2 Off-shelf flow of chilled water

Turbidity currents (weak, strong)

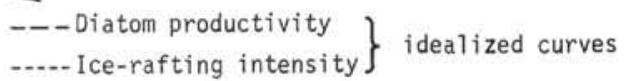

Figure 8. Schematic representation of the Antarctic continental margin during the first half of a glacial cycle (from Tucholke et al., this volume). 
undergone extensive alteration and recrystallization. The established Southern Ocean biostratigraphic zonal schemes were applicable throughout the area; Bukry (1974) has suggested a silicoflagellate zonation based on DSDP material recovered during Legs 28 and 29 near Antarctica. All sites except 324 (not drilled to sufficient depth) contain arenaceous foraminifera of early Miocene, or possibly late Oligocene, age. Planktonic calcareous foraminifera occur in the Danian at Site 323 on the abyssal plain and in the Pliocene-Pleistocene sediments at Sites 324 and 325 on the upper continental rise. A calcareous deep-water benthonic foraminiferal assemblage is associated with the early Miocene arenaceous foraminifera at Site 325 . Calcareous nannoplankton are rare, but they were recovered from thin chalky beds in the Maestrichtian and Danian of Site 323 and the lower Miocene of Site 325.

Fossils were found near the bottom of the hole at each site, and they indicate the ages of the oldest sediments penetrated. At Site 322 the basal 5 meters of sediment contains arenaceous foraminifera of probable early Miocene, or possible late Oligocene, age. At Site 323 the deepest sediments, within a few meters of basalt, contain late Maestrichtian nannoplankton. Higher in the sequence a probable unconformity exists between the early Miocene arenaceous foraminifera in Core 13 and the Danian calcareous fossils in Core 15. At Site 324 the lowest sediments are probably early Pliocene on the basis of radiolarians and diatoms. At Site 325 the oldest sediments contain early Miocene, or possibly late Oligocene, arenaceous and calcareous foraminifera.

\section{PALEOENVIRONMENTS}

Despite the limitations of modest recovery of scattered cores at only four sites, some inferences may be drawn and speculations offered about ancient water depths, carbonate compensation depths, surface water temperatures, and water currents. All of the sediments at the four sites seem to have formed at bathyal or abyssal depths, but only a few rough estimates of actual depths are possible. Deposition of the MaestrichtianDanian pelagic beds at Site 323 required a tranquil environment, and these enriched sediments may be ridgecrest deposits. The Danian calcareous and arenaceous foraminiferal fauna suggests water depths of 1500 to 2000 meters; these sediments are probably from the shallowest environments encountered in the four sites. An early Miocene arenaceous foraminiferal fauna was found in the three holes indicating water depths greater than 2000 meters.

The sediments recovered at the four sites on the abyssal plain and the continental rise were probably deposited mainly below the ancient carbonate compensation depth; less than 4 meters of core rich in calcareous microfossils were collected during the entire cruise. At Site 323 a few, poorly preserved calcareous nannoplankton occur in the Maestrichtian claystone. However, both calcareous foraminifera and nannoplankton are common in the overlying Danian beds. The apparent temporary deepening of the carbonate compensation depth at this site from the Maestrichtian to the Danian is in contrast to the shoaling inferred from other sites by Worsley (1974). Sparse and scattered cal- careous foraminifera and nannoplankton occur in the lower Miocene beds at Site 325 on the continental rise. At Sites 322 and 323 on the abyssal plain a few, probably reworked, calcareous benthonic foraminifera were found in the middle Miocene. Sites 324 and 325 on the continental rise yielded a sparse Pliocene-Pleistocene fauna of calcareous planktonic foraminifera. In the modern seas near Antarctica, however, the carbonate compensation depth shows striking lateral variations, and solution of tests by bottom water is probably widespread (Echols, 1971); hence any paleobathymetric interpretations based solely on carbonate content of circum-Antarctic sediments would be unwise.

Certain changes in the microfossil assemblages imply changes in seawater temperatures during the late Cenozoic. In the middle Miocene, for the first time, siliceous microfossils became dominant at all three deeply drilled sites. This indicates a major change in the physical oceanography of the area, probably related to the developing Antarctic glaciation. At Site 323 middle Miocene and early late Miocene radiolarians of a type found only in modern tropical or subtropical areas suggest periodic incursions of warm waters. Diatom abundances at Site 322 imply that the polar front reached this locality by the late Miocene; Hough (1956) showed that modern diatom oozes form a belt lying just south of the Antarctic Convergence. The abundant siliceous microfossils in Core 1 at Site 324 may indicate a climatic warming during the Pleistocene and a southward shift in the limits of pack-ice compared to earlier and modern conditions.

The two abyssal plain holes yielded evidence for the inception during the early Tertiary of a strong bottom current which is possibly the modern Antarctic Circumpolar Current. The age and significance of the basalt flow at the bottom of Site 322 are in doubt, but the evidence suggests that this is probably oceanic basement of (?) Paleocene age. Foraminifera within the basal 3 meters of the overlying sediments are early Miocene, or possibly late Oligocene age; the younger Miocene sediments show some sorting and contain poorly preserved, current-polished arenaceous foraminifera. The basaltsediment contact was not recovered, but it may represent an unconformity. At Site 323 early Miocene, or possibly late Oligocene, foraminifera occur 39 meters above Danian calcareous microfossils; the barren intervening section probably contains a major unconformity. Thus, significant sediment erosion at both sites is likely between the Paleocene and the late Oligocene or early Miocene when sedimentation resumed under a diminishing current. This deep circulation event may be related to initiation of the circumpolar flow when South America separated from the Antarctic Peninsula. The time of opening of the Drake Passage is poorly known, but the magnetic anomalies suggest that it formed no later than the early Miocene; Frakes and Kemp (1973) argue that it was open during the Oligocene.

It is interesting to compare these new results with other evidence about the history of the Antarctic Circumpolar Current. Kennett et al. (1972), based on data from DSDP Leg 21, show the existence in the southwest Pacific Ocean of a widespread regional unconformity centered in the early Oligocene. The beginning of the 
modern Antarctic Circumpolar Current has been estimated at 36-41 m.y.B.P. by Foster (1974) from Australian echinoids, at about 30 m.y.B.P. by Kennett et al. (1974) from the results of DSDP Leg 29 near New Zealand, and at 27-28 m.y.B.P. by Jenkins (1974) from planktonic foraminifera in the southwest Pacific Ocean area; these estimates range from late Eocene to late Oligocene.

The sediments underlying the continental rise and the abyssal plain are predominantly detritus from Antarctica, and turbidity currents have played a major role in the development of the deep continental margin. The distinctive sedimentary structures and sorting characteristics show that turbidites are numerous at Sites 322,323 , and 325 and have been forming since the early Miocene.

Hollister and Heezen (1967) reported the existence of a westward-flowing contour current along the continental rise in the Bellingshausen Sea. At Site 325 beneath this flow turbidites are predominant, but there are some laminated and sorted silts which are probably contourites. However, Site 324 , also beneath the present axis of this flow, contains numerous well-sorted silts and sands which occur as thin interbeds in clay; these are interpreted as contourites. Sediment waves and small dunes on the seismic profiles (Figure 7) provide further evidence of the contour current which may have begun in the Miocene. The sedimentary model proposed here indicates that the strength of the contour current should increase as the intensity of Antarctic glaciation increases (Figure 8).

\section{ANTARCTIC GLACIATION}

Although there is widespread evidence in Antarctica for higher levels of the ice sheet in the past, the problem of the antiquity of glaciation received little attention until recent years. The Jones Mountains in West Antarctica were discovered in 1960 , and the existence there of a glaciated pavement of Miocene age was reported by Craddock et al. (1964) and Rutford et al. $(1968,1972)$. Barton (1963) inferred that cooling had begun in Antarctica by early Miocene from two floras in the South Shetland Islands. Connolly and Ewing (1965) interpreted the lowest ice-rafted debris in eight Vema piston cores as the Pliocene-Pleistocene contact. Opdyke et al. (1966) reported that four piston cores near Antarctica contained ice-rafted debris in sediments as old as 2.5 m.y., and Goodell (1966) extended the range to 5 m.y.B.P. Bandy (1966) argued for intermittent if not continuous ice on Antarctica from 11 m.y.B.P. Hays and Opdyke (1967) found evidence for widespread Antarctic glaciation by 4 m.y.B.P., and Geitzenauer et al. (1968) reported possibly ice-rafted grains in a middle Eocene unit in a 17-meter core from the Southeast Pacific Basin.

LeMasurier (1970) described subglacial hyaloclastites from West Antarctica with $\mathrm{K}-\mathrm{Ar}$ apparent ages as old as Eocene. Mandra and Mandra (1970), however, concluded from silicoflagellate studies that the late Eocene climate near the Antarctic Peninsula was warmtemperate or warmer. Kennett and Fillon (1970) and Margolis and Kennett $(1970,1971)$ studied ice-rafted sands in deep-sea cores and postulated Antarctic glacial advances during the early Eocene, middle Eocene, and Oligocene. Denton et al. (1971) argued, on the basis of early Tertiary floras, that Antarctica did not have a full ice sheet before the late Miocene, and Bandy et al. (1971) deduced a major cooling during the late Miocene from the distributions of planktonic microfossils. From her studies of palynomorphs in continental shelf sediments, Kemp (1972) concluded that Antarctica remained vegetated at least until the middle Eocene, and Frakes and Kemp (1973) advocated only limited ice during the Eocene, growth of the main ice sheet during the Oligocene, and culmination of glaciation in the late Miocene. Ciesielski and Weaver (1974) drew paleotemperature curves for the early Pliocene on the basis of silicoflagellate distributions. They found that the water temperature 4 m.y.B.P. was as much as $10^{\circ} \mathrm{C}$ warmer than at present, perhaps too warm for the existence of an ice sheet in West Antarctica. Shackleton and Kennett (1975) reported that the surface water temperature at DSDP Site 277 on the Campbell Plateau fell from $20^{\circ} \mathrm{C}$ in the early Eocene to $7^{\circ} \mathrm{C}$ in the early Oligocene, and Kennett et al. (1975) gave a summary of Antarctic climatic events during the Cenozoic. LeMasurier and Wade (in press) discussed subglacial palagonite breccias in West Antarctica which show the presence of an ice sheet by at least the Oligocene.

Cores from the four Leg 35 sites were studied for evidence of ice-rafted debris in the form of small dropstones and quartz grains with distinctive microscopic surface textures suggestive of glacial transport. The two abyssal plain sites, those farthest from the continent, yielded little ice-rafted debris. At Site 322 the oldest icerafted debris is late Miocene, and at Site 323 it is probably middle Miocene. Glacial debris is abundant, however, in the two holes closer to the continent. At Site 324 all but two cores yielded ice-rafted debris, and the oldest glacial material is early Pliocene (from the bottom of the last core). The first eight cores at Site 325 have each yielded ice-rafted debris, and the oldest is probably early Miocene in age.

The failure of Site 324 in Pliocene sand was a disappointment because it was being drilled to test the Miocene glaciation in the Jones Mountains just to the south. Nevertheless, ice-rafted debris was found in Miocene sediments at each of the other three sites. The age of the oldest glacial material at Site 325 is about 1617 m.y.B.P., but we emphasize that. no Eocene, and possibly no Oligocene, sediments were recovered during Leg 35. Our proposed sedimentation model links the Miocene and younger sediments of the continental rise and the abyssal plain with the intensity of glaciation in Antarctica; our interpretations of glacial intensity are given below with the geologic history.

\section{DIAGENESIS}

The sediments of the Southeast Pacific Basin have undergone extensive diagenetic changes even though only buried to depths of a few hundred meters. The change to a consolidated state at about 300 meters and the downhole increase in velocity have been noted above. The lower beds, at Site 325 for example, are commonly cemented by calcite and/or silica as a result of the dissolution of microfossil tests. At Site 323 diatoms dis- 
appear below about 400 meters through recrystallization into silicified claystone and chert. Authigenic minerals such as illite/smectite, clinoptilolite, and potash feldspar are present in the lower sedimentary units at Sites 322, 323 , and 324. These authigenic minerals probably formed through the alteration of volcanic glass or ash, but they may have been derived from the predominant terrigenous detritus. Oxygen isotope studies suggest that alteration of volcanic debris and/or the underlying basalt has been significant.

The basalts penetrated at the bottom of the two abyssal plain sites have undergone significant mineralogical and chemical changes since burial by sediments. The alteration at Site 322 is relatively slight and has formed poorly recrystallized smectite, phillipsite, and minor amounts of calcite. At Site 323 possible lowtemperature hydrothermal alteration has produced wellrecrystallized smectite, celadonite, goethite, and abundant calcite; the sediments just above the basalt are enriched in barium. This alteration has occurred under a thin sediment cover, and carbon isotopes indicate that the carbonate formed through the decay of organic material in the sediments. Potassium enrichment of the basalts at both sites is suggested by the anomalously low $\mathrm{K}$-Ar ages.

The interstitial pore waters at all four sites display similar and pronounced downhole chemical gradients. There are clear downhole decreases in dissolved magnesium, potassium, carbon dioxide, and alkalinity, but dissolved calcium increases. Magnesium is depleted by the formation of montmorillonite, and potassium by the formation of zeolites and feldspar. The decrease in alkalinity and carbon dioxide is due to the precipitation of calcite in veins and as cement. The increase in calcium results from the alteration of plagioclase and pyroxene in the basalt and in the detrital sediments.

\section{GEOLOGIC HISTORY}

Since there is no sea floor known to be older than Cretaceous in the Southeast Pacific Basin, the earlier history of the region must be studied in the geology of the bounding continents-South America and Antarctica. During the late Paleozoic and early Mesozoic these two continents comprised parts of the ancient supercontinent of Gondwanaland (Figure 9). During the Phanerozoic geosynclines developed along the Pacific margin of Gondwanaland (Borrello, 1969; Craddock, 1972a), and these underwent subsequent orogeny marked by folding of layered rocks, regional metamorphism, and emplacement of igneous plutons. Orogens of four different ages have been identified (Craddock, 1975), and this active continental margin can be traced through the now dispersed fragments of Gondwanaland from South America through West Antarctica to New Zealand and Australia. These orogens are generally arranged in an older-to-younger progression from the Precambrian shields toward the Pacific Basin, but the pattern is more complicated in detail. Krylov et al. (1970) report possible Precambrian rocks in Marie Byrd Land near the Pacific coast of West Antarctica. Mehnert et al. (1975) have shown that the strongly deformed Jurassic sedimentary and volcanic strata of the southern Antarctic Peninsula were folded between the Late
Jurassic and the Middle Cretaceous. Charrier (1973) describes five separate compressive phases in the Andes Mountains between the Late Jurassic and the late Miocene.

The chronology of Gondwanaland fragmentation is poorly defined. Dietz and Holden (1970) postulated that the breakup of Pangaea began during the Triassic, and Larson and LaFountain (1970) suggest that the opening of the Atlantic began in the Triassic. Basaltic rocks in southern Brazil, which may be related to the opening of the south Atlantic, were dated as Lower Cretaceous by McDougall and Ruegg (1966), but Amaral et al. (1966) indicate that some rocks are Jurassic. Dalziel (1974) and Dott (in preparation) suggested that the widespread Jurassic volcanic rocks in southern South America and the Antarctic Peninsula are related to the breakup of Gonwanaland. Briden et al. (1974), however, portray Gondwanaland as still intact in the Middle Cretaceous.

The area of the Leg 35 drilling appears to have been a deep oceanic region since at least the late Paleozoic, a part of the vast ocean that formerly bordered Gondwanaland, although no oceanic crust older than Cretaceous has been found. The orogens provide a record of continuing tectonism along this active continental margin during much of Phanerozoic time and suggest the convergence of plates and subduction. Thus the early deep-sea record of this ocean has been lost by subduction, much of it beneath the Antarctic continental margin. Force (1973) argues for active spreading in the ancient Pacific during the early Triassic from geologic evidence in circum-Pacific geosynclines. LeMasurier and Wade (in press) infer convergence and subduction along the continental margin of West Antarctica during the Mesozoic from the composition and distribution of igneous rocks. Beginning with the late Cretaceous, however, the geologic history of the region is also preserved in the deposits on the ocean floor.

\section{Cretaceous}

The oldest known rocks in the Southeast Pacific Basin are the Maestrichtian claystones at Site 323, and the magnetic anomalies (Pitman et al., 1968) suggest the existence of a considerable area of Cretaceous sea floor. Herron (1971) considered the Chile Ridge as a remnant of a larger northwest-trending ridge in the Cretaceous, but the Pacific-Antarctic Ridge existed by the late Cretaceous and since then has spread about three different poles of rotation (Christoffel and Falconer, 1973; Carroll et al., 1974). Bowin (1974) described the westward migration of this spreading axis from the eastern Pacific in the late Cretaceous past Australia in the early Tertiary and into the Gulf of Aden in the late Tertiary. Christoffel and Falconer (1972) date the separation of West Antarctica and the New Zealand Plateau as late Cretaceous (about 81 m.y.B.P.). After this separation began, differential movement between West Antarctica and East Antarctica seems necessary, at least until the East Antarctica-Australia separation commenced in the early Tertiary (Craddock, 1975; Molnar et al., 1975). The West Antarctica-New Zealand and New Zealand-Australia separations began at about the same time (McDougall and van der Lingen, 1974). The spreading ridge inferred to have formed the Ellsworth 


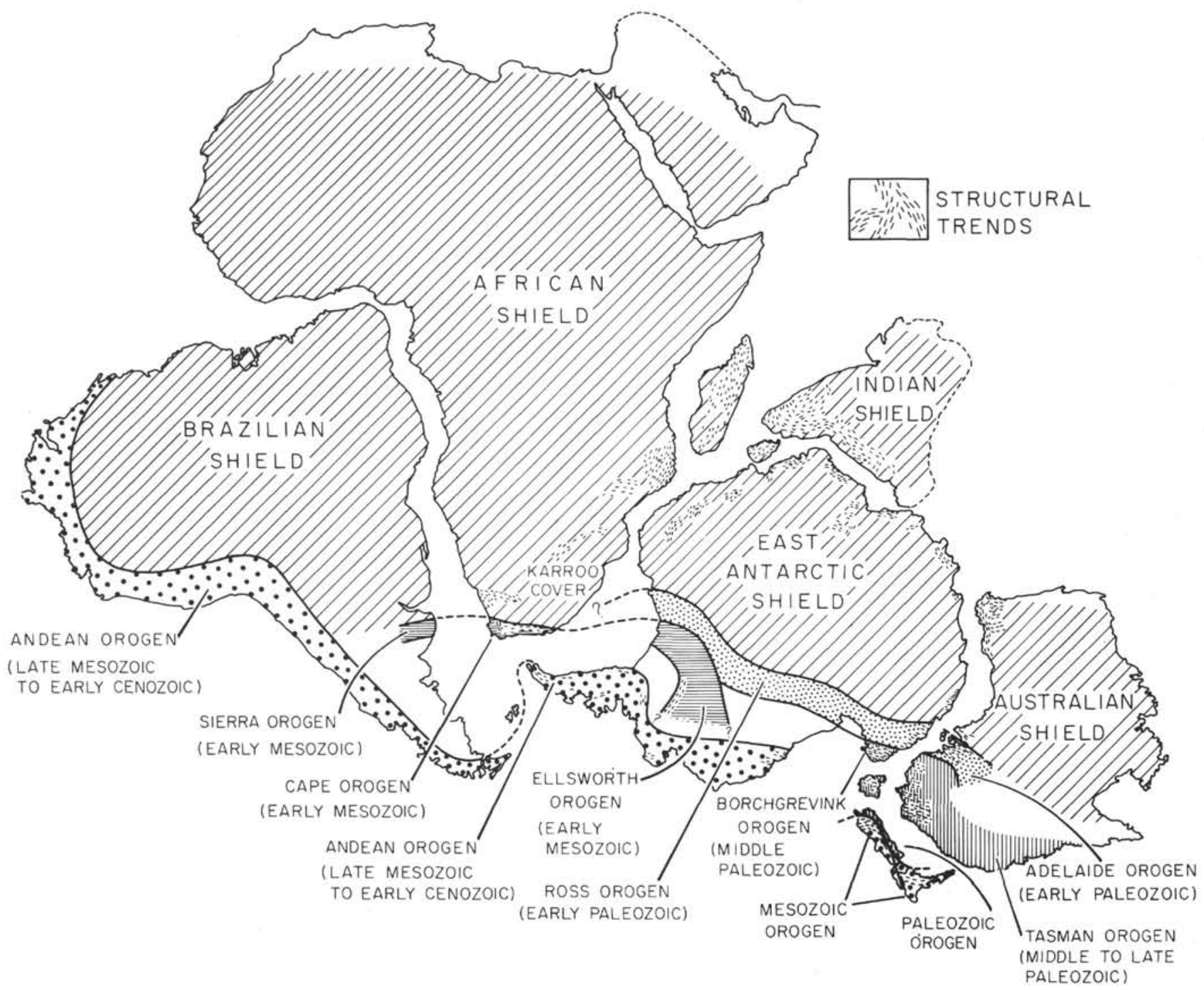

Figure 9. Schematic tectonic map of Gondwanaland in the early Mesozoic before fragmentation, with the addition of the younger late Mesozoic-early Cenozoic orogen. The shapes and structures of the Gondwanaland fragments as they exist today have been used in this reassembly. Areas in the western Pacific which today lie north of Australia-New Zealand and which may have been part of Gondwanaland are not included. (Modified after Craddock in Bushnell and Craddock, 1970.)

anomalies near Alexander Island southwest of the Tula Fracture Zone may have become active in the late Cretaceous, but the magnetic patterns are poorly defined at present.

The crust at Site 323 is considered to have formed during the late Cretaceous at a spreading axis, probably the Pacific-Antarctic Ridge. Water depth at the ridge crest was 1500-2000 meters, and the ridge crest was close to the carbonate compensation depth. The Maestrichtian sediments here are brown pelagic claystones with a few calcareous nannoplankton. These are the only Cretaceous rocks which were encountered during the drilling on Leg 35.

In southern South America the main Andean orogeny deformation was middle Cretaceous (Dalziel, 1974; Dalziel et al., 1975) although the emplacement of plutons continued into the Miocene (Dott, in preparation). Matthews et al. (1974) have discovered evi- dence in the western Pacific for a middle Cretaceous eustatic sea level rise which they attribute to an interval of rapid sea-floor spreading; the Andean orogeny is coeval and may have the same cause. Dalziel and Elliot (1971, 1973) consider the separation South America and Antarctica clearly to postdate the Andean orogeny; Katz (1973), however, emphasizes differences in the late Mesozoic-Cenozoic histories of the two areas. Cretaceous intrusives are numerous in the Antarctic Peninsula and westward along coastal Antarctica, but strong compressive deformation may have ended by the middle Cretaceous.

\section{Paleogene}

The only Paleogene material recovered during Leg 35 is the Danian (early Paleocene) sediment overlying the Maestrichtian near the bottom of Site 323. The Danian sequence consists of pelagic claystone with a few beds 
rich in calcareous fossils. Foraminifera indicate a water depth of 1500-2000 meters, and terrigenous detritus is probably not present. The carbonate compensation depth appears to have descended and then risen again during the Danian.

During Leg 35 no sediment was recovered from the upper Paleocene, the Eocene, and most or all of the Oligocene. During earlier work a piston core taken at $58^{\circ} \mathrm{S}, 91^{\circ} \mathrm{W}$ yielded middle Eocene clay, silt, and calcareous ooze below an unconformity at a depth of 13 meters. Surface textures on some quartz grains suggest that ice-rafted debris was reaching this site during the middle Eocene. Frakes (1972), however, concluded that vegetation was widespread in Antarctica during the Eocene.

The crust at three Leg 35 sites probably formed during the Paleogene. Basement at Site 322 is most likely Paleocene, but older or younger ages cannot be excluded. At Site 324 projection of the closest Ellsworth magnetic anomalies suggests a Paleocene age, but there is much uncertainty about the true basement age. Relatively good information indicates a late Oligocene formation of the crust at Site 325 .

The history of the Chile Ridge is poorly known, but it was probably active by the Paleogene. Morgan et al. (1969) suggested that the Chile Ridge might be no older than 16 m.y., and Herron and Hayes (1969) recognized two periods of activity, the last beginning 10 m.y.B.P. More recent work suggests that to the south of $46^{\circ} \mathrm{S}$ spreading began in the Eocene or Oligocene and that this segment of the ridge was subducted in the early Miocene.

The peninsula set of magnetic anomalies lie northwest of the Antarctic Peninsula between the Hero and Tula Fractures zones. Spreading from this axis appears to have begun during the Eocene and to have ended in the early Miocene when the ridge was subducted at the Antarctic Peninsula.

The Ellsworth magnetic anomalies southwest of the Tula Fracture Zone were formed by a spreading ridge which seems to have subducted at the Antarctic margin during the Eocene. This inferred ridge probably was a sediment barrier which prevented any Antarctic detritus from reaching Sites 323 and 324 until the Eocene. The subduction of this ridge may be related to the formation of overthrusts in Cretaceous strata on Alexander Island described by Horne (1967), and it may have caused extension and widespread volcanism on the continental rise and in coastal West Antarctica. LeMasurier and Wade (in press) infer a change from crustal compression to extension between 80 and 53 m.y.B.P. in Marie Byrd Land.

Vaguely defined magnetic anomaly patterns in the Southeast Pacific Basin and the Scotia Sea suggest that a triple junction, probably initiated during the Eocene, began to open the Drake Passage during the Oligocene. The modern Antarctic Circumpolar Current could not develop until the Drake Passage had opened; evidence from the Southwest Pacific suggests that this current came into existence during the Oligocene. The formation of this current seems to have caused substantial sediment scour at Sites 322 and 323.

Dott (in preparation) argues that the tectonic zones from South America to Antarctica may have remained intact through the Eocene, and thus the opening of the Scotia Sea has probably taken place since the early Oligocene. He emphasizes the importance of a midCenozoic tectonic discontinuity, and suggests that all of the following may have happened during the Oligocene: (1) separation of South Georgia Island from Tierra del Fuego, (2) breakup of the Andean belt, (3) major jump of the East Pacific Rise, and (4) initial collision of the Chile Ridge with South America.

\section{Miocene}

A thick Miocene sequence was encountered at three sites, and the fourth site failed in the Pliocene. The Miocene sediments consist of clays, silts, and sandsterrigenous detritus derived from Antarctica. Much of this material was transported to the deep ocean by turbidity currents and some of it was deposited by bottom currents. The Antarctic Circumpolar Current diminished somewhat from its initial vigor, but it continued to affect abyssal plain sedimentation during the Miocene. Early Miocene foraminifera at these three sites indicate water depths in excess of 2000 meters.

Ice-rafted debris occurs at all three sites in Miocene sediments, most abundantly at Site 325 closest to the continent. Interpretation of the sediments in terms of the model proposed as a result of Leg 35 drilling (Tucholke et al., this volume) indicates that glaciation in Antarctica was weak in the earliest Miocene, moderate by the middle Miocene, extensive by about late middle Miocene, and probably full by sometime during the late Miocene.

The Miocene was a time of overall climatic cooling in the region. The South Shetland Islands remained vegetated during the early Miocene, but the flora shows that cooling had begun (Barton, 1963). During the middle Miocene siliceous microfossils became abundant and dominant in the Leg 35 area, probably reflecting the growth of the Antarctic ice sheet and the cooling of the seas. The distribution of diatoms at Site 322 suggests that the polar front had advanced northward to that point by the late Miocene. Certain radiolarians at Site 323 , however, indicate temporary incursions of warmer waters there during the middle and early late Miocene. An abrupt change in the heavy mineral suite at Site 325 may be related to intensive glaciation during the late Miocene. Bandy (1968) and Kennett and Watkins (1974) inferred a pronounced late Miocene cooling from studies of foraminiferal assemblages; this conclusion has been contested, however, by Beu (1974) on the basis of work on New Zealand molluscs.

Volcanic material is a significant component of the lower beds of the sedimentary sequence at Sites 322 and 325 , indicating the presence of a volcanic source during early and middle Miocene time. Gonzalez-Ferran et al. (1970) have described upper Cenozoic volcanic rocks as old as Miocene in the South Shetland Islands.

Important changes in the regional tectonic pattern occurred during the Miocene. The spreading axis which formed the peninsula magnetic anomaly set was subducted at the margin of the Antarctic Peninsula during the early to middle Miocene. The spreading axis to the northeast in the Drake Passage appears to have become active during the early Miocene; it is interesting that Rex and Baker (1973) have reported a granodiorite from the 
South Shetland Islands with a K-Ar age of late Miocene. Winn (1975) concluded that the separation of South Georgia Island from Tierra del Fuego began between the early Oligocene and the middle Miocene. Charrier (1973) considered the latest spreading phase on the Chile Ridge to have begun in the middle to late Miocene. Subduction of the southern end of the Chile Ridge beneath southern South America probably was underway by the early Miocene.

\section{Pliocene}

Detrital sediments of Pliocene age were recovered at all four sites. Numerous sand and silt beds are present, and ice-rafted debris is abundant. At the three sites where calculations were possible, very high sedimentation rates of $10-20 \mathrm{~cm} / 1000 \mathrm{yr}$ were recorded for the latest Miocene and early Pliocene. Horizon R, a distinctive seismic reflector, is probably related to the vigorous turbidity current and ice-rafting activity characteristic of this interval of full Antarctic glaciation (Tucholke and Houtz, this volume). Goodell and Watkins (1968) show that northward the upper Cenozoic sediments are thin due to the effect of the Antarctic Circumpolar Current on sedimentation processes.

The cores from Site 324 can be compared to the proposed sedimentation model, and they suggest fluctuations in the intensity of Antarctic glaciation during the Pliocene and Pleistocene. Cores 1 (Pleistocene) and 9 (early Pliocene) indicate moderate glaciation, but the intervening cores indicate mainly extensive glaciation with a few intervals of only moderate glaciation. The wellsorted silt beds suggest that the contour current was vigorous along the upper continental rise during the Pliocene. The volcanic material in the sediments at this site may have been derived from the Jones Mountains to the south.

The history of Antarctic climatic fluctuation during the Pliocene is beginning to emerge. Ciesielski and Weaver (1974) found evidence for a warm interval about 4 m.y.B.P., perhaps too warm for an ice sheet to have existed in West Antarctica, followed by a period of declining temperatures into the middle Pliocene. Blank and Margolis (1975) recorded a distinct cooling at 4.74.8 m.y.B.P. and a marked increase in ice-rafted debris at about 3.75 m.y.B.P. Unconformities between Antarctica and Australia (Watkins and Kennett, 1972) indicate an increase in the velocity of the Antarctic Bottom Water sometime during the last $3.5 \mathrm{~m} . \mathrm{y}$. Weaver and Ciesielski (1973) inferred a major temperature decline beginning about 3.92 m.y. B.P. and suggested that the polar front may not have advanced to its present position until 2.4 m.y.B.P. In the Ross Sea, Fillon (1975) found a widespread disconformity between sediments $0.7 \mathrm{~m} . \mathrm{y}$. or younger and those $2.4 \mathrm{~m} . \mathrm{y}$. or older, probably due to cooling with expansion of the Ross Ice Shelf and increased circulation of bottom water.

The magnetic anomaly patterns in the Drake Passage suggest that spreading from this axis may have ceased, or greatly slowed, during the Pliocene.

\section{Quaternary}

The only Quaternary sediments recovered during Leg 35 are from four Pleistocene cores at Site 324. The
Pleistocene beds are clays with scattered ice-rafted debris and well-sorted silt and sand in beds and stringers. In our sedimentation model the current Antarctic glaciation would be described as moderate to extensive. It is likely that glaciation during the Pleistocene fluctuated between moderate and extensive, but our data are insufficient to provide a test. The youngest core at this site is the only one with abundant fossils; this may indicate a brief warming and southward retreat of the pack-ice margin during the late Pleistocene. Goodell (1973) provides a good review of Quaternary sediments in the seas near Antarctica.

During the Quaternary Antarctica has been rather quiet tectonically, and the South Shetland Islands, separated from the northern Antarctic Peninsula by the Bransfield Strait, may have been the only active part of the continent. Late Cenozoic volcanoes occur along much of the Pacific coast of Antarctica, and a few are presently active, notably Deception Island in the South Shetland Islands. Although the magnetic anomaly patterns suggest that spreading in the Drake Passage may have ended during the Pliocene, some continued activity is suggested by (1) the well-developed trench, (2) scattered seismicity in the Drake Passage (Barazangi and Dorman, 1969), and (3) modern volcanism at Deception Island. The Bransfield Strait may be an extensional back-arc trough. Forsyth (1975) described fault plane solutions from the Scotia Sea and gave an interesting tectonic interpretation (Figure 10); he postulates sinistral slip along not only the north Scotia Ridge but the south Scotia Ridge and Shackleton Fracture Zone as well. Perhaps a middle Cenozoic triple junction lying just to the west caused the opening of the Scotia Sea in a north-south direction, and a main shear developed along the south side of the new Scotia plate. This new plate, partially coupled to the South American plate, may have overridden the triple junction; this might have eventually formed the spreading center in the eastern Scotia Sea, which became active about 7.5 m.y.B.P. (Barker, 1972). The volcanic rocks in the South Sandwich Islands are low in potash and close to primitive oceanic basalts (Frolova et al., 1974).

Gansser (1973) divided the Andes Mountains into three segments; he separates the central and southern Andes at $46-47^{\circ} \mathrm{S}$ where the Chile Ridge comes aground. The southern Andes are tectonically relatively quiet, with few earthquakes or active volcanoes; indeed, Gonzalez-Ferran (1972) showed 48 active volcanoes in Chile, and only two lie south of $46^{\circ} \mathrm{S}$. Fault plane solutions from the Chile Ridge (Forsyth, 1972; Anderson et al., 1974) indicate a strike-slip movement along roughly east-west transform faults, and the Chile Ridge south of about $46^{\circ} \mathrm{S}$ appears to have subducted beneath the South American margin during the Miocene. This subduction may be a factor in the drowned character of the west coast of southern Chile, and even in the postPliocene westward tilting and drainage reversal described by Katz (1962).

In the southern Andes the convergence rate between the Antarctic and South American plates is relatively low. Barker and Griffiths (1972) put the rate at 1.2-1.4 $\mathrm{cm} / \mathrm{yr}$, and Forsyth (1975) at $2 \mathrm{~cm} / \mathrm{yr}$. The slower convergence rate here than to the north must be a factor in 


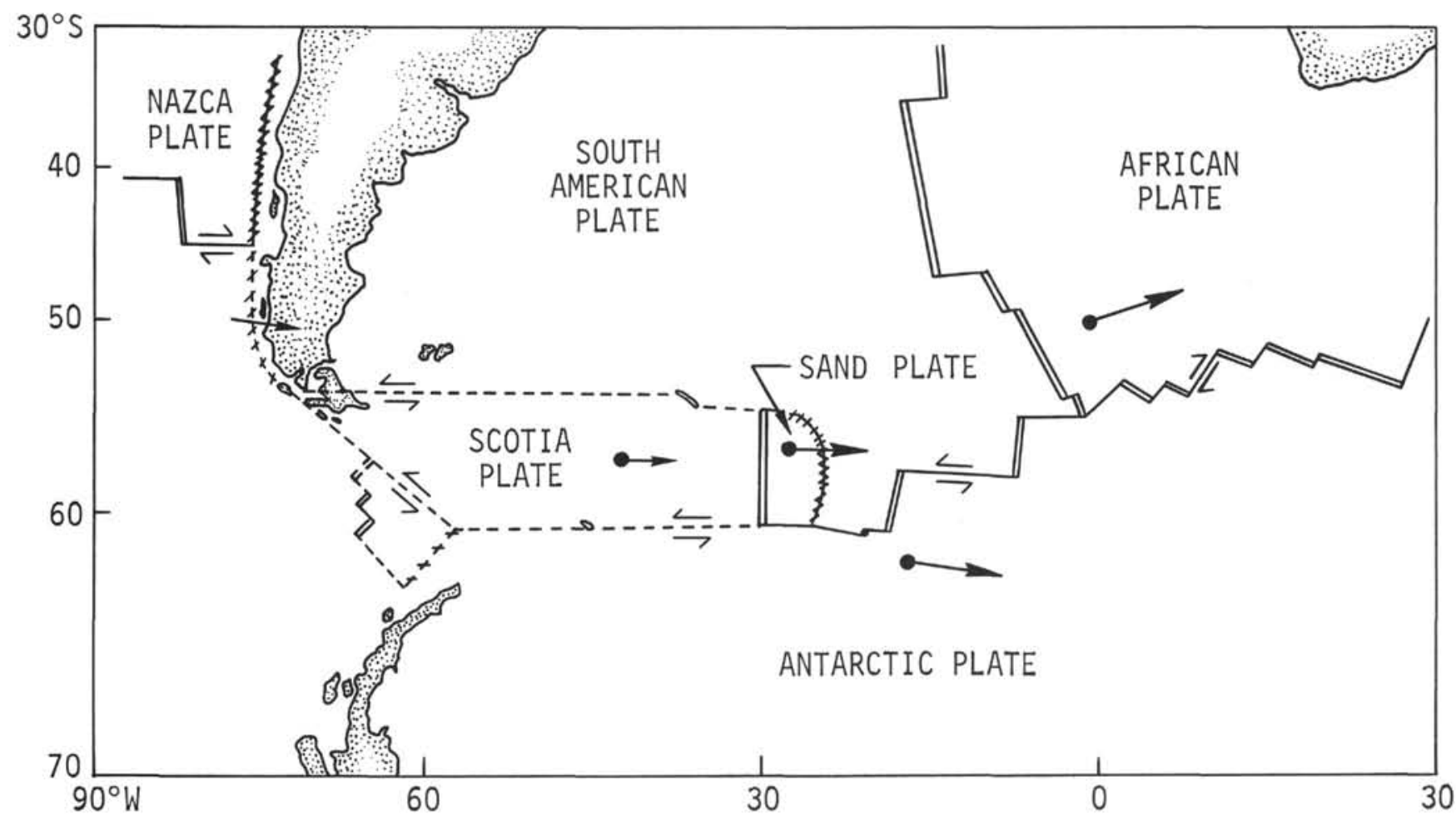

Figure 10. Summary of inferred plate motions in the South Atlantic from Forsyth, 1975. Heavy arrows indicate direction of motion of plates relative to a coordinate system fixed with respect to South America. Light arrows indicate observed sense of motion on plate boundaries. Double lines are spreading centers, single lines are transform faults, and hatched lines are subduction zones. Lines are dashed where location or nature of boundary is uncertain.

the greatly reduced volcanicity and seismicity. Sugisaki (1972) correlates andesitic volcanism with plate convergence at rates greater than $2.5 \mathrm{~cm} / \mathrm{yr}$.

Interesting changes in the tectonic patterns along the western margin of South America have developed during the subduction cycle. Miller (1970) showed that structural trends in the older rocks strike toward the Pacific and are truncated along the modern coast. Rutland (1971) explained this truncation and the eastward shift in the volcanic axis by removal of crust during subduction. Gonzalez-Ferran (1974), however, noted that the volcanic axis shifted $150-200 \mathrm{~km}$ eastward from Miocene to Pliocene but $50 \mathrm{~km}$ westward from Pliocene to the present; he suggested that these shifts might be related to variations in subduction velocity.

Because we recovered Quaternary sediments only at Site 324, most of this summary of Quaternary history is drawn from the observations of other workers in the marine and continental realms of the region. The four holes drilled on Leg 35, however, modest as they are in number, provide important new information about the preceding Cretaceous and Tertiary history of the Southeast Pacific Basin.

\section{ACKNOWLEDGMENTS}

We sincerely thank all participants in the Leg 35 project, particularly our shipboard colleagues. The contributions of each individual to the cruise and to this synthesis are evident in the other papers in this volume. We are especially grateful to Paula Worstell for her patience, skill, and dedication, both at sea and ashore, in guiding this book to completion.
Scientists at Lamont-Doherty Geological Observatory, in particular John Ewing and Robert Houtz, provided us with complete seismic profiler data for the area. We also appreciate advance copies of papers in press from Robert H. Dott, $\mathrm{Jr}$. and Wesley LeMasurier, and helpful discussions with Dott and Robert D. Winn. The assistance of Barbara Van Dyk in lengthy data reduction after the cruise is gratefully acknowledged.

\section{REFERENCES}

Amaral, G., Cordani, U.G., Kawashita, K., and Reynolds, J.H., 1966. Potassium-argon dates of basaltic rocks from Southern Brazil: Geochim. Cosmochim. Acta, v. 30, p. 159-189.

Anderson, R.N., Forsyth, D.W., Molnar, P., and Mammerickx, J., 1974. Fault plane solutions of earthquakes on the Nazca plate boundaries and the Easter Plate: Earth Planet. Sci. Lett., v. 24, p. 188-202.

Ashcroft, W.A., 1972. Crustal structure of the South Shetland Islands and Bransfield Strait: British Columbia Surv. Sci. Rept. No. 66, London.

Austin, P.M., 1975. Paleogeographic and paleotectonic models for the New Zealand geosyncline in eastern Gondwanaland: Geol. Soc. Am. Bull., v. 86, p. 1230-1234.

Bandy, O.L., 1966. Faunal evidence of Miocene-to-Recent paleoclimatology in Antarctic (abstract): Am. Assoc. Petrol. Geol. Bull., v. 50, p. 643-644.

1968. Cycles in Neogene paleooceanography and eustatic changes: Palaeogeogr., Palaeoclimatol., Palaeoecol., v. 5, p. 63-75.

Bandy, O.L., Casey R.E., and Wright, R.C., 1971. Late Neogene planktonic zonation, magnetic reversals, and radiometric dates, Antarctic to the tropics. In Reid, J.L. (Ed.), Antarctic Oceanology I, Antarctic Res. Ser.: v. 15, p. 1-26. 
Barazangi, M. and Dorman, J., 1969. World seismicity maps compiled from ESSA, Coast and Geodetic Survey, epicenter data, 1961-1967: Seis. Soc. Am., v. 59, p. 369.

Barker, P.F., 1972. Spreading center in the East Scotia Sea. Earth Planet. Sci. Lett., v. 15, p. 123-132.

Barker, P.F. and Griffiths, D.H., 1972. The evolution of the Scotia Ridge and Scotia Sea: Phil. Trans. Roy. Soc. London, Ser. A., v. 271 , p. 151-183.

Barton, C.M., 1963. The significance of two separate Tertiary plant assemblages from King George Island, South Shetland Islands (abstract): SCAR Bull., p. 288-289.

Bence, A.E., Papike, J.J., Chandrasekharam, D., Cameron, M., and Canenisch, S., 1973. Petrology of basalts from Leg 15 of the Deep Sea Drilling Project: the central Caribbean. In DSDP conference on igneous and metamorphic rocks: EOS (Am. Geophys. Union Trans.), v. 54, p. 995-998.

Beu, A.G., 1974. Molluscan evidence of warm sea temperatures in New Zealand during Kapitean (late Miocene) and Waipipian (middle Pliocene) time: New Zealand J. Geol. Geophys., v. 17, p. 465-479.

Biscaye, P.E., 1965. Mineralogy and sedimentation of Recent deep-sea clay in the Atlantic Ocean and adjacent seas and oceans: Geol. Soc. Am. Bull., v. 76, p. 803-831.

Blank, R.G. and Margolis, S.V., 1975. Pliocene climatic and glacial history of Antarctica as revealed by southeast Indian Ocean deep-sea cores: Geol. Soc. Am. Bull., v. 86, p. 1058-1066.

Bonatti, E., 1965. Palagonite hyaloclastics and alteration of volcanic glass in the ocean: Bull. Volcanol., v. 28, p. $257-$ 269.

1967. Mechanisms of deep-sea volcanism in the South Pacific. In Abelson, P.H. (Ed.), Researches in geochemistry: v. 2, p. 453-491.

Borrello, A.V., 1969. Los geosinclines de la Argentina: Direc. Nacional Geol. Min. Ann. 14, 188 p.

Böstrom, K. and Peterson, M.N.A., 1966. Precipitates from hydrothermal exhalations on the East Pacific Rise: Econ. Geol., v. 61, p. 1258-1265.

1969. The origin of aluminum-poor sediments in areas of high heat flow on the East Pacific Rise: Mar. Geol., v. 7, p. 427-447.

Böstrom, K., Peterson, M., Joensuu, O., and Fisher, D., 1969. Aluminum-poor ferromanganoan sediments on active oceanic ridges: J. Geophys. Res., v. 74, p. 3261-3270.

Bowin, C., 1974. Migration of a pattern of plate motion: Earth Planet. Sci., Lett., v. 21, p. 400-404.

Briden, J.C., Dreway, G.E., and Smith, A.G., 1974. Phanerozoic equal-area world maps: J. Geol., v. 82, p. 555-574.

Bukry, D., 1974. Stratigraphic value of silicoflagellates in nontropical regions: Geol. Soc. Am. Bull., v. 85, p. 1905-1906.

Bushnell, V.C. and Craddock, C. (Ed.), 1970. Geologic Maps of Antarctica: Folio 12, Antarctic Map Folio Series: New York (American Geographical Society).

Carroll, B.M., Simmons, G., and Erickson, A.J., 1974. Sea floor spreading in the Southeast Pacific between $36^{\circ}$ and $52^{\circ} \mathrm{S}$ (abstract): EOS (Am. Geophys. Union Trans.), v. 55, p. 301 .

Charrier, R., 1973. Interruptions of spreading and the compressive tectonic phases of the meridional Andes: Earth Planet. Sci. Lett., v. 20, p. 242-249.

Christensen, N.I. and Salisbury, M.H., 1972. Sea floor spreading, progressive alteration of layer 2 basalts and associated changes in seismic velocities: Earth Planet. Sci. Lett., v. 15 , p. 367-375.

Christensen, N.I., Frey, D., MacDougal, D., Melson, W.G., Peterson, M.N.A., Thompson, G. and Watkins, N., 1973. Conference summary, DSDP Conference on igneous and metamorphic rocks of the oceanic crust: EOS, v. 54, p. $972-981$.
Christoffel, D.A. and Falconer, R.K.H., 1972. Marine magnetic measurements in the southwest Pacific Ocean and the identification of new tectonic features. In Hayes, D.E. (Ed.), Antarctic Oceanology II, Antarctic Res. Ser.: v. 19, p. 197-209.

1973. Changes in the direction of sea floor spreading in the Southwest Pacific. In Oceanography of the South Pacific 1972: Wellington (New Zealand Comm. Unesco), p. 241-247.

Ciesielski, P.F. and Weaver, F.M., 1974. Early Pliocene temperature changes in the Antarctic seas: Geology, v. 2, p. 511-515.

Conolly, J.R. and Ewing, M., 1965. Ice-rafted detritus as a climatic indicator in Antarctic deep-sea cores: Science, v. 150 , p. $1822-1824$.

Cooper, R.A., 1975. New Zealand and Southeast Australia in the early Paleozoic: New Zealand J. Geol. Geophys., v. 18 , p. 1-20.

Craddock, C., 1972a. Antarctic tectonics. In Adie, R.J. (Ed.), Antarctic geology and geophysics, Oslo (Universitetsforlaget), p. 449-455.

1972b. Geologic Map of Antarctica: New York (American Geographical Society), 1:5,000,000.

1975. Tectonic evolution of the Pacific margin of Gondwanaland. In Campbell, K.S.W. (Ed.), Gondwana geology: Canberra (Australia National University Press), p. 609-618.

Craddock, C., Bastien, T.W., and Rutford, R.H., 1964. Geology of the Jones Mountains. In Adie, R.J. (Ed.), Antarctic geology: Amsterdam (North Holland Publishing Co.), p. 171-187.

Cronan, D.S., van Andel, T.H., Heath, G.R., Dinkelman, M.G., Bennett, R.H., Bukry, D., Charleston, S., Kaneps, A., Rodolfo, K.S., and Yeats, R.S., 1972. Iron-rich basal sediments from the eastern equatorial Pacific: Leg 16, Deep Sea Drilling Project: Science, v. 175, p. 61-63.

Dalziel, I.W.D., 1974. Evolution of the margins of the Scotia Sea. In Burk, C.A. and Drake, C.L. (Eds.), The geology of continental margins: New York (Springer-Verlag), p. $567-$ 580 .

Dalziel, I.W.D. and Elliot, D.H., 1971. Evolution of the Scotia Arc: Nature, v. 233, p. 246-252.

1973. The Scotia Arc and Antarctic margin. In Nairn, A.E.M. and Stehli, F.G. (Eds.), The ocean basins and margins: v. 1, the South Atlantic, p. 171-246.

Dalziel, I.W.D., Dott, R.H., Jr., Winn, R.D., Jr., and Bruhn, R.L., 1975. Tectonic relations of South Georgia Island to the Southernmost Andes: Geol. Soc. Am. Bull., v. 86, p. $1034-1040$.

Davies, T.A. and Supko, P.R., 1973. Oceanic sediments and their diagenesis: some examples from deep sea drilling: J. Sediment. Petrol., v. 43, p. 381-390.

Denton, G.H., Armstrong, R.L., and Stuiver, M., 1971. The late Cenozoic glacial history of Antarctica. In Turekian, K.K. (Ed.), The Late Cenozoic glacial ages: New Haven and London (Yale University Press), p. 267-306.

Dietz, R.S. and Holden, J.C., 1970. Reconstruction of Pangaea: breakup and dispersion of continents, Permian to present: J. Geophys. Res., v. 75, p. 4939-4956.

Dott, R.H., Jr., in preparation. Contrasts in tectonic history along the eastern Pacific rim-emphasizing the late Cenozoic revolution.

Echols, R.J., 1971. Distribution of foraminifera in sediments of the Scotia Sea area, Antarctic waters. In Reid, J.L. (Ed.), Antarctic Oceanology I, Antarctic Res. Ser.: v. 15, p. 93168.

Elderfield, H., 1972. Effects of volcanism on water chemistry, Deception Island, Antarctica: Mar. Geol., v. 13, p. M1M6. 
Engel, A.E.J., Engel, C.G., and Havens, R.G., 1965. Chemical characteristics of oceanic basalt and the upper mantle: Geol. Soc. Am. Bull., v. 76, p. 719-734.

Ewing, M., Houtz, R., and Ewing, J., 1969. South Pacific sediment distribution: J. Geophys. Res., v. 74, p. 2477-2493.

Fillon, R.H., 1975. Late Cenozoic paleo-oceanography of the Ross Sea, Antarctica: Geol. Soc. Am. Bull., v. 86, p. 839845.

Force, E.R., 1973. Permian-Triassic contact relations in circum-Pacific geosynclines: Pacific Geol., no. 6, p. 19-23.

Ford, A.B., 1975. Antarctic deep-sea basált, Southeast Indian Ocean and Balleny Basin, DSDP Leg 28. In Hayes, D.E., Frakes, L.A., et al., Initial Reports of the Deep Sea Drilling Project, Volume 28: Washington (U.S. Government Printing Office), p. 835-859.

Forsyth, D.W., 1972. Mechanisms of earthquakes and plate motions in the East Pacific: Earth Planet. Sci. Lett., v. 17, p. 189-193.

1975. Fault plane solutions and tectonics of the South Atlantic and Scotia Sea: J. Geophys. Res., v. 80, p. 1429-1443.

Foster, R.J., 1974. Eocene echinoids and the Drake Passage: Nature, v. 249 , p. 751.

Frakes, L.A., 1972. Paleoclimatology of the Southern Ocean: Antarctic J. U.S., v. 7, p. 189-190.

Frakes, L.A. and Kemp, E.M., 1972. Generation of sedimentary facies on a spreading ocean: Nature, v. 236, p. 114117.

1973. Paleogene continental positions and evolution of climate. In Tarling, D.H. and Runcorn, S.K. (Eds.), Implications of continental drift to the earth sciences: v. 1, p. 539-558.

Frolova, T.I., Rudnik, G.B., and Orlenok, V.V., 1974. Main features of structure and evolution of the South Antilles and the Scotia Sea: Geotectonics, No. 3, p. 176-183.

Gansser, A., 1973. Facts and theories on the Andes: J. Geol. Soc. London, v. 129, p. 93-131.

Geitzenauer, K.R., Margolis, S.V., and Edwards, D.S., 1968. Evidence consistent with Eocene glaciation in a South Pacific deep sea core: Earth Planet. Sci. Lett., v. 4, p. 173177.

Goodell, H.G., 1966. Antarctic marine geology: Geotimes, v. 11, p. $24-26$.

1969. The marine geology of the Southern Oceans: Antarctic J. U.S., v. 4, p. 167-168.

1973. The sediments. In Marine Sediments of the Southern Oceans, Folio 17, Antarctic Map Folio Series: New York (American Geographical Society).

Goodell, H.G. and Watkins, N.D., 1968. The paleomagnetic stratigraphy of the Southern Ocean: $20^{\circ}$ West to $160^{\circ}$ East longitude: Deep-Sea Res., v. 15, p. 89-112.

Gonzalez-Ferran, O., 1972. Distribución del volcanismo activo de Chile y la reciente erupcion del volcán Villarrica: El Primer Symposium Cartográfico Nacional, Santiago, p. 191-207.

1974. The Cenozoic Volcanism in Chile and West Antarctica: A Review (abstract): Int. Symp. Volcanol. (Santiago).

Gonzalez-Ferran, O., Katsui, O., and Katsui, Y., 1970. Integrated study of the late Cenozoic volcanism of the South Shetland Islands, Antarctica: INACH Ser. Cient., v. 1 , p. 123-174.

Griffin, J.J., Windom, H., and Goldberg, E.D., 1968. The distribution of clay minerals in the world ocean: Deep-Sea Res., v. 15, p. 433-459.

Griffiths, J.R., 1974. Revised continental fit of Australia and Antarctica: Nature, v. 249, p. 336-338.

Hart, R., 1970. Chemical exchange between sea water and deep ocean basalts: Earth Planet. Sci. Lett., v. 9, p. 269279.
Hays, J.D. and Opdyke, N.D., 1967. Antarctic radiolaria, magnetic reversals and climatic change: Science, v. 158, p. 1001-1011.

Heezen, B.C. and C.D. Hollister, 1971. The face of the deep: Oxford (Oxford University Press).

Heezen, B.C. and Tharp, M., 1972. Morphology of the sea floor. In Morphology of the earth in the Antarctic and Subantarctic, Folio 16, Antarctic Map Folio Series: New York (Am. Geogr. Soc.).

Heirtzler, J.R., 1971. The evolution of the southern oceans: In Quam, L.O. (Ed.), Research in the Antarctic: Washington (Am. Assoc. Advancement of Science), Publication No. 93, p. 667-684.

Herron, E.M., 1971. Crustal plates and sea-floor spreading in the Southeastern Pacific. In Reid, J.L. (Ed.), Antarctic Oceanology I, Antarctic Res. Ser.: v. 15, p. 229-237.

Herron, E.M. and Hayes, D.E., 1969. A geophysical study of the Chile Ridge: Earth Planet. Sci. Lett., v. 6, p. 77-83.

Hollister, C.D. and Heezen, B.C., 1967. The floor of the Bellingshausen Sea. In Hersey, J.B. (Ed.), Deep sea photography: Baltimore (John Hopkins Press), p. 177-189.

Horne, R.R., 1967. Structural geology of part of Southeastern Alexander Island: Brit. Antarctic Surv. Bull., no. 11, p. 122.

Hough, J.L., 1956. Sediment distribution in the Southern Oceans around Antarctica: J. Sediment. Petrol., v. 26, p. 301-306.

Jenkins, D.G., 1974. Initiation of the proto circum-Antarctic current: Nature, v. 252, p. 371-373.

Katz, H.R., 1962. Fracture patterns and structural history in the Sub-Andean belt of southernmost Chile: J. Geol., v. 70 , p. $595-603$.

1972. Plate tectonics and orogenic belts in the Southeast Pacific: Nature, v. 237, p. 331-332.

1973. Contrasts in tectonic evolution of orogenic belts in the Southeast Pacific: J. Roy. Soc. New Zealand, v. 3, p. 333-362.

Keany, J., Ledbetter, M.T., Huang, T., and Watkins, N.D., 1974. Regional studies of ice-rafted detritus in SubAntarctic deep-sea sediments: initial results and evaluation of potential significance, models and experimental methods (abstract): EOS (Am. Geophys. Union Trans.), v. 55, p. 312 .

Kemp, E.M., 1972. Recycled palynomorphs in continental shelf sediments from Antarctica: Antarctic J. U.S., v. 7, p. 190-191.

Kennett, J.P. and Fillon, R.H., 1970. Micropaleontological and associated studies of Southern Ocean deep-sea cores: Antarctic J. U.S., v. 5, p. 181-182.

Kennett, J.P. and Watkins, N.D., 1974. Late Miocene-Early Pliocene paleomagnetic stratigraphy paleoclimatology, and biostratigraphy in New Zealand: Geol. Soc. Am. Bull., v. 85, p. $1385-1398$.

Kennett, J.P., Burns, R.E., Andrews, J.E., Churkin, M., Jr., Davies, T.A., Dumitrica, P., Edwards, A.R., Galehouse, J.S., Packham, G.H., and van der Lingen, G.J., 1972. Australian-Antarctic continental drift, palaeocirculation changes and Oligocene deep-sea erosion: Nature Phys. Sci., v. 239 , p. $51-55$.

Kennett, J.P., Houtz, R.E., Andrews, P.B., Edwards, A.R., Gostin, V.A., Hajos, M., Hampton, M.A., Jenkins, D.G., Margolis, S.V., Ovenshine, A.T., Perch-Nielsen, K., 1974. Development of the Circum-Antarctic current: Science, v. 186 , p. 144-147.

Kennett, J.P., Houtz, R.E., Andrews, P.E., Edwards, A.R., Gostin, V.A., Hajos, M., Kampton, M., Jenkins, D.G., Margolis, S.V., Ovenshine, A.T., and Perch-Nielsen, K., 1975. Cenozoic paleooceanography in the Southwest Pacific Ocean, Antarctic glaciation, and the development of the Circum-Antarctic Current. In Kennett, J.P., Houtz, 
R.E., et al., Initial Reports of the Deep Sea Drilling Project, Volume 29: Washington (U.S. Government Printing Office), p. 1155-1169.

Kolpack, R.L., 1967. Surface sediments of Drake Passage: Antarctic J. U.S., v. 2, p. 183.

Krylov, A.Y., Lopatin, B.G., and Mazina, T.I., 1970. Age of rocks in the Ford Ranges and on Ruppert Coast (Western Part of Byrd Land): Soviet Ant. Exped. Inform. Bull., v. 8, p. 64-66.

Larson, E.E. and LaFountain, L., 1970. Timing of the breakup of the continents around the Atlantic as determined by paleomagnetism: Earth Planet. Sci. Lett., v. 8, p. 341-351.

LeMasurier, W.E., 1970. Volcanic evidence for early Tertiary glaciation in Marie Byrd Land: Antarctic J. U.S., v. 5, p. $154-155$.

LeMasurier, W.E. and Wade, F.A., in press. Volcanic history in Marie Byrd Sand: implications with regard to southern hemisphere tectonic reconstructions: presented at International Symposium on Andean and Antarctic Volcanological Problems, Santiago, Chile, 1974.

Lisitzin, A.P., 1973. Sediment thicknesses and sedimentation rates in the oceans during the Mesozoic and Cenozoic, according to the results of deep-sea drilling: Oceanology, v. 13 , p. $215-227$.

Mandra, Y.T. and Mandra, H., 1970. Antarctic Tertiary marine climate based on silicoflagellates: Antarctic J. U.S., v. 5 , p. $178-180$.

Margolis, S.V. and J.P. Kennett, 1970. Antarctic glaciation during the Tertiary recorded in Sub-Antarctic deep-sea cores: Science, v. 170, p. 1085-1087.

1971. Cenozoic paleoglacial history of Antarctica recorded in Subantarctic deep-sea cores: Am. J. Sci., v. 271 , p. 1-36.

Matthews, J.L., Heezan, B.C., Catalano, R., Coogan, A., Tharp, M., Natland J., and Rawson, M., 1974. Cretaceous drowning of reefs on Mid-Pacific and Japanese guyots: Science, v. 184 , p. $462-464$.

McBirney, A.R., 1971. Oceanic volcanism: A review: Rev. Geophys. Space Phys., v. 3, p. 523-556.

McDougall, I. and Rulegg, N.R., 1966. Potassium-argon dates on the Serra Geral Formation of South America: Geochim. Cosmochim. Acta, v. 30, p. 191-195.

McDougall, I. and van der Lingen, G.J., 1974. Age of the rhyolites of the Lord Howe Rise and the evolution of the southwest Pacific Ocean: Earth Planet. Sci. Lett., v. 21, p. $117-126$,

Mehnert, H.H., P.D. Rowley, and D.L. Schmidt, 1975. K-Ar ages of plutonic rocks in the Lassiter Coast area, Antarctica: J. Res., U.S. Geol. Surv., v. 3, p. 233-236.

Miller, V.H., 1970. Das Problem des hypothetischen, Pazifischen Kontinentes gesehen von der Chilenischen Pazifikkuste: Geol. Rundsch., v. 59, p. 927-938.

Molnar, P., Atwater, T., Mammerickx, J., and Smith, S.W., 1975. Magnetic anomalies, bathymetry and the tectonic evolution of the South Pacific since the Late Cretaceous: Geophys. J., v. 40, p. 383-420.

Morgan, J.W., Vogt, P.R., and Falls, D.F., 1969. Magnetic anomalies and sea floor spreading on the Chile Rise: Nature, v. 222, p. 137-142.

Northrop, J., 1973. Seismicity gaps in the Pacific-Antarctic ridge and East Pacific Rise. In Oceanography of the South Pacific 1972: Wellington (New Zealand Comm. Unesco), p. $285-290$.

Opdyke, N.D., Glass, B., Hays, J.D., and Foster, J., 1966. Paleomagnetic study of Antarctic deep-sea cores: Science, v. 154 , p. $349-357$.

Ozima, M., Saito, K., and Joshima, M., 1973. K-Ar, ${ }^{40} \mathrm{Ar}-{ }^{39} \mathrm{Ar}$ dating and magnetic studies of Leg 7 and Leg 17 basalt samples. In DSDP Conf. on igneous and metamorphic rocks: EOS (Am. Geophys. Union Trans.), v. 54, p. 989.

Payne, R.R., Conolly, J.R., and Abbot, W.H., 1972. Turbidite muds within diatom ooze off Antarctica: Pleistocene sediment variation defined by closely spaced piston cores: Geol. Soc. Am. Bull., v. 83, p. 482-486.

Pitman, W.C. III, and Heirtzler, J.R., 1966. Magnetic anomalies over the Pacific-Antarctic Ridge: Science, v. 154 , p. 1164 .

Pitman, W.C., III, Herron, E.M., and Heirtzler, J.R., 1968. Magnetic anomalies in the Pacific and sea-floor spreading: J. Geophys. Res., v. 73, p. 2069-2085.

Rateev, M.A., Gorbunova, Z.N., Lisitzin, A.P., and Nosov, G.L., 1969. Distribution of clay minerals in the oceans: Sedimentology, v. 13, p. 24-43.

Rex, D.C. and Baker, P.E., 1973. Age and petrology of the Cornwallis Island granodiorite: British Antarctic Surv. Bull., no. 32, p. 55-61.

Rutford, R.H., Craddock, C., and Bastien, T.W., 1968. Late Tertiary glaciation and sea-level changes in Antarctica: Palaeogeogr., Palaeoclimatol., Palaeoecol., v. 5, p. 15-39.

Rutford, R.H., Craddock, C., White, C.M., and Armstrong, R.L., 1972. Tertiary glaciation in the Jones Mountains. In Adie, R.J. (Ed.), Antarctic geology and geophysics: Oslo (Universitetsforlaget), p. 239-243.

Rutland, R.W.R., 1971. Andean orogeny and ocean floor spreading: Nature, v. 233 , p. 252-255.

Saito, T., Burckle, L.H., and Hays, J.D., 1974. Pre-Quaternary sediment cores and dredgings. In Hay, W.W. (Ed.), Studies in Paleooceanography: Soc. Econ. Paleontol. Mineral., Spec. Publ. No. 20, p. 6-36.

Salisbury, M.H. and Christensen, N.I., 1973. Progressive weathering of submarine basalt with age: further evidence of sea-floor spreading: Geology, v. 1, p. 63-64.

Shackleton, N.J. and Kennett, J.P., 1975. Paleotemperature history of the Cenozoic and the initiation of Antarctic glaciation: oxygen and carbon isotope analyses in DSDP Sites 277, 279, and 281. In Kennett, J.P., Houtz, R.E., et al., Initial Reports of the Deep Sea Drilling Project, Volume 29: Washington (U.S. Government Printing Office), p. 743-755.

Sugisaki, R., 1972. Tectonic aspects of Andesite Line: Nature Phys. Sci., v. 240 , p. 109-111.

Turekian, K., 1965. Some aspects of the geochemistry of marine sediments. In Riley, J. and Skirrow, G. (Eds.), Chemical oceanography: New York (Academic Press), v. 2 , p. $81-126$.

Watkins, N.D. and Kennett, J.P., 1972. Regional sedimentary disconformities and upper Cenozoic changes in bottom water velocities between Australasia and Antarctica. In Hayes, D.E. (Ed.), Antarctic Oceanology II, Antarctic Res. Ser.: v. 19 , p. 273-293.

Watkins, N.D., Keany, J., Ledbetter, M., and Huang, T.C., 1974. Ice-rafted debris in subantarctic Eltanin deep sea sedimentary core: Antarctic J. U.S., v. 9, p. 256.

Weaver, F.M. and Ciesielski, P.F., 1973. Pliocene paleoclimatic history recorded in Antarctic deep sea cores (abstract): Geol. Soc. Am. Abst., v. 5, p. 856-857.

Winn, R.D., 1975. Late Mesozoic flysch of Tierra del Fuego and South Georgia Island: a sedimentological approach to lithosphere plate restoration: Ph.D. thesis, University of Wisconsin.

Worsley, T., 1974. The Cretaceous-Tertiary boundary event in the ocean. In May, W.W. (Ed.), Studies in paleooceanography: Soc. Econ. Paleontol. Mineral., Spec. Publ. No. 20, p. 94-125. 